Schulich School of Law, Dalhousie University

Schulich Law Scholars

Research Papers, Working Papers, Conference

Papers

Faculty Scholarship

$11-26-2018$

\title{
A Dualist Approach to Offshore Renewable Energy Governance: A Case for the Third World
}

Adebayo Majekolagbe

Dalhousie University - Dalhousie University, Schulich School of Law, Students,

Adebayo.Majekolagbe@dal.ca

Follow this and additional works at: https://digitalcommons.schulichlaw.dal.ca/working_papers

\section{Recommended Citation}

Majekolagbe, Adebayo, "A Dualist Approach to Offshore Renewable Energy Governance: A Case for the Third World" (2018). Research Papers, Working Papers, Conference Papers. 2.

https://digitalcommons.schulichlaw.dal.ca/working_papers/2

This Working Paper is brought to you for free and open access by the Faculty Scholarship at Schulich Law Scholars. It has been accepted for inclusion in Research Papers, Working Papers, Conference Papers by an authorized administrator of Schulich Law Scholars. For more information, please contact hannah.steeves@dal.ca. 


\section{A DUALIST APPROACH TO OFFSHORE RENEWABLE ENERGY GOVERNANCE: A CASE FOR THE THIRD WORLD}

\section{Abstract}

The need for an environmentally sustainable alternative to fossil-sourced energy has led to a global increase in offshore renewable energy (ORE) ventures in the past decade. With fast-advancing technologies, these ventures are moving into deeper waters, putting the likelihood of ORE installations in the High Seas in sight. Concerns about potential conflict with other traditional uses of the marine space, marine pollution, inefficient and inequitable deployments have been raised. However, asides from few State-based regulatory frameworks, there is no international legal framework to regulate this burgeoning ORE industry. Adopting a socio-legal approach, this paper mainstreams Arvid Pardo's argument for the equitable management of the ocean space as an ecological whole, to propose a dualist approach to ORE governance. This paper contends that the current global ORE structure is inequitable and inefficient and proposes ways existing structures can be adapted to regulate the burgeoning industry. Using Nigeria (and West Africa) as case study, recommendations have been made on the roles to be played by States and the International Community in a global ORE governance framework. 


\section{A DUALIST APPROACH TO OFFSHORE RENEWABLE ENERGY GOVERNANCE - A CASE FOR THE THIRD WORLD}

I am sure that the genius of man will not fail to unfold the various mysteries of oceans and seas. ${ }^{1}$

\section{INTRODUCTION}

The quest to achieve a balance between the need for a sustainable environment and an adequate supply of energy ${ }^{2}$ to the world's growing population ${ }^{3}$ is one of the greatest challenges of the $21^{\text {st }}$ century. ${ }^{4}$ More so as the world's prevalent source of energy, fossil fuel, ${ }^{5}$ doubles as the highest source of carbon dioxide $\left(\mathrm{CO}_{2}\right)$ emissions, resulting in climate change. ${ }^{6}$ Hence, it is only logical that there is a transition from fossil energy to non-fossil energy to hold the global temperature below $2^{0} \mathrm{C}$ above pre-industrial levels. ${ }^{7}$ At this juncture, the question of how the rising global energy demand ${ }^{8}$ will be met lingers. The seemingly uncomplex answer to this question is a recourse to renewable energy. It has been posited that it is possible for renewable energy to completely cater to human energy

\footnotetext{
${ }^{1}$ Ismail Fahmy's response to Arvid Pardo's presentation to the United Nations General Assembly on the oceans and the sea bed on November 1, 1967. See UNGA, 22nd Sess, 1515th Mtg, UN Doc A/6695 [1967].

${ }^{2}$ Except where specifically stated, the use of the word 'energy' in this paper refers to 'electricity'. Also, the term offshore renewable energy is alternated with 'ocean energy'. In this paper's context, 'renewable energy' means "all forms of energy produced from renewable sources in a sustainable manner". See Statute of the International Renewable Energy Agency, 26 January 2009, 2700 UNTS 47934 at art III (entered into force on 8 July 2010) [IRENA Statute]. Offshore renewable energy in this paper means all forms of renewable energy generated from the territorial sea, exclusive economic zone and the High Sea.

${ }^{3}$ The United Nations Department of Economic and Social Affairs projects that the "The current world population of 7.6 billion is expected to reach 8.6 billion in 2030, 9.8 billion in 2050 and 11.2 billion in 2100". See "World Population Prospects: The 2017 Revision", United Nations Department of Economic and Social Affairs (21 June 2017) online: <https://www.un.org/development/desa/publications/world-population-prospects-the-2017-
} revision.html>.

${ }^{4}$ According to the former Director of the World Bank's Energy and Extractive Global Practice, Charles Feinstein, the greatest challenges facing the planet today are "meeting the growing demand for energy in a manner that is both reliable and affordable; second, ensuring energy access that is socially equitable; and third, enhancing the environmental sustainability of energy". See Randy Showstack, "Report calls for Balancing Energy Security, Energy Equity, and Environmental Concerns" (9 December 2014) EOS, online: <https://eos.org/articles/reportcalls-balancing-energy-security-energy-equity-environmental-concerns>.

${ }^{5}$ The world's total energy consumption for 2016 entailed - about 4500 Million Tonnes Oil Equivalent (MTOE) from crude oil, 3000 MTOE from gas, less than 300 MTOE from nuclear energy, about 900 MTOE from hydroelectricity, less than 200 MTOE from renewables (solar, wind, biomass) and about 3600 MTOE from coal. See British Petroleum, "BP Statistical Review of World Energy June 2017" online: (2017) 66 BP Statistical Review of World Energy at 10 <https://www.bp.com/content/dam/bp/en/corporate/pdf/energyeconomics/statistical-review-2017/bp-statistical-review-of-world-energy-2017-full-report.pdf>

${ }^{6} \mathrm{CO}_{2}$ emissions from fossil fuel and industry is said to amount to $91 \%$ of the total emissions between 2006 2015. See Corinne Le Quere et al, "Global Carbon Budget 2016" (2016) 8 Earth Science Data 605 at 625.

${ }^{7}$ The Paris Agreement provides that participating States agree to hold "the increase in the global average temperature to well below $2{ }^{\circ} \mathrm{C}$ above pre-industrial levels and to pursue efforts to limit the temperature increase to $1.5{ }^{\circ} \mathrm{C}$ above pre-industrial levels, recognizing that this would significantly reduce the risks and impacts of climate change". See Paris Agreement, 12 December 2015, UNTS 54113 at art II (entered into force 4 November 2016) (Paris Agreement)

${ }^{8}$ The International Energy Agency projects that by 2040, there will be a 30\% increase in global energy demand. See International Energy Agency, "World Energy Outlook, 2017, (Executive Summary)" (14 November 2017) online: World Energy Outlook, <https://www.iea.org/weo2017/>. Further, the growth in the use of electric cars, buses and trains, will consequently increase in global energy demand. Recently, the Automobile Association of America reported that 30 million Americans are likely to buy electric vehicles in 2018. See Robert Ferris, "Demand for electric vehicles bucks low gas prices, says AAA", CNBC (18 April 2017), online: <https://www.cnbc.com/2017/04/17/demand-for-electric-vehicles-bucks-low-gas-prices-says-aaa.html> 
(electricity) demands. ${ }^{9}$ Although this is desirable, the present reality is not as encouraging. ${ }^{10}$ In any case, an ambitious $100 \%$ transition to sustainable energy is an aspiration we cannot afford to lessen. In tandem with this goal, the oceans have been turned to as a possible source of renewable energy; and over the years, the ocean has given man perhaps more renewable energy options than can be sourced onshore. ${ }^{11}$

In the light of the multifarious uses of the sea, the prospect of an increase in offshore renewable energy projects and the possibility of conflicts in respect of these multiple uses, there have been calls for a regulatory framework for offshore renewable energy activities. The absence of a regulatory framework for the global offshore renewable energy (ORE) enterprise has immense 'functional' and 'justice-related' dimensions. Hence, this paper, in the main, contends that the current 'unregulated' structure of the global ORE industry is both inefficient and inequitable, and proposes ways current institutional frameworks can be refashioned and realigned to benefit subaltern States.

As shown in part II of this work, some proponents of a regulated offshore renewable energy (ORE) enterprise, have largely employed a State-based regulatory approach; a few others have advocated for an international and/or regional governance structure. State-based regulatory approach is mostly premised on the 1982 United Nations Convention of the Law of the Sea, which confers sovereignty and sovereign rights ${ }^{12}$ on coastal States in respect of their territorial waters and exclusive economic zones (and continental shelf), respectively. It will be further contended in this paper that this State-based approach not only negates the underlying principles of equity and cooperation that UNCLOS is founded on, but it also contradicts the erga omnes obligation to mitigate climate change. Drawing from Richard Barnes' views, ${ }^{13}$ State-based approach is further inconsistent with the inherent straddling nature of ocean sourced renewable energy. The distinct characteristics of ORE vis-à-vis trends in the international ORE enterprise are considered in Part III. Mainstreaming Arvid

\footnotetext{
${ }^{9}$ Christopher Clack, et al, "Evaluation of a Proposal for reliable low-cost grid power with $100 \%$ wind, water and solar" (2017) 114 Proceedings of the National Academy of Sciences of the United States of America, 6722 6727.

${ }^{10}$ However, renewable energy is said to have been the fastest growing energy source in 2016. See British Petroleum, supra note 5 at 3.

${ }^{11}$ Asides offshore (ocean) exclusive renewable energy options like Ocean Thermal Energy Conversion (OTEC), tidal energy and wave energy, wind energy is increasingly being more favoured offshore than onshore, while traditionally land based options like solar energy and biomass can also to some extent be based offshore.

${ }^{12}$ United Nations Convention of the Law of the Sea, 10 December 1982, 1833 UNTS 31363 (entered into force on 16 November 1994) (UNCLOS) employs the terms 'sovereignty' and 'sovereign rights' differently. For example, while Article 2(1) vests 'sovereignty' in a coastal State over its territorial sea, Article 56(1)(a) gives the coastal State 'sovereign rights' for specific purposes contained in the provision. These two concepts 'sovereignty' and 'sovereign rights' must be distinguished from another concept used in Article 56(1)(b) of UNCLOS 'jurisdiction'. Considering the interrelationship between these three concepts, Professor Horace Robertson, Jr. opined that "all that can be concluded from the history of the term is that "sovereign rights" are something less than "sovereignty," but something more than jurisdiction and control". See Horace Robertson, JNR, "Navigation in the Exclusive Economic Zone" (1984) 24:4 Va J Int L 865 at 875 - 876, footnote 52. In the Island of Palmas case (Netherlands, USA) [1928] II Reports of International Arbitral Awards 829 at 838, the Tribunal defined 'sovereignty' as the independence of a State, "in regard to a portion of the globe ... to exercise therein, to the exclusion of any other State, the functions of a State". While 'territory' on the other hand, the High Court of Australia in New South Wales v. The Commonwealth [1975] 50 ALJR 218 construed 'sovereign rights' to imply, "exclusive and paramount rights to exploit together with all the power necessary to secure the principal rights".

${ }^{13}$ Richard Barnes, "Energy Sovereignty in the Marine Spaces" in Nigel Bankes \& Seline Trevisanut, eds, Energy from the Sea - An International Law Perspective on Ocean Energy (Boston: BRILL NIJHOFF, 2014$) 13$.
} 
Pardo's 'common heritage' argument, this paper critically appraises ORE-related provisions of UNCLOS in Part IV, with specific focus on his argument for non-developed states participation in global ocean governance and the benefits therefrom. As opposed to aligning with either side of the State-based versus international ORE governance regime debate,${ }^{14}$ this paper canvasses a dualist governance model. ${ }^{15}$ Using Nigeria as a case study, it is posited in Part V that a dualist governance approach is critical to energy development in poor developing States which suffer the most from the effects of climate change, but which have no capacity to develop their ORE potentials. Albeit, there are broader implications to the dualist approach proposed in this paper. Its consideration here is limited to the delimitation of the functions and responsibilities of individual States (using Nigeria as a test case) and the international community (including regional bodies) in a dualist offshore energy governance structure. It is hoped that this work will inform a more comprehensive research into the issues it considers, with the ultimate aim of providing an equitable and sustainable legal framework for offshore renewables. A summary of the recommendations made in the paper is contained in Part VI.

\section{CONCEPTUALIZING OFFSHORE RENEWABLES}

In considering the subject of 'offshore renewables', three concepts stand out - renewable energy as a form of energy; the ocean as a 'source' of energy; and the climate (environment) as a primary 'beneficiary'. Inherent in these three concepts, however, is their construct both as State-based and international concerns. For example, although the subject of energy is generally deemed a national issue (as it directly affects individuals domiciled in sovereign States), its connection to the subject of climate change and its status as a fundamental need of the $21^{\text {st }}$ century man bequeaths to it an international 'human right' outlook. ${ }^{16}$ At the same time, the ocean and the environment are subjects of both domestic and international concerns. ${ }^{17}$ The foregoing is the basis for a key thesis of this paper that ORE governance

\footnotetext{
${ }^{14}$ In this paper, State-based regulatory framework includes sub-national regulatory frameworks within States with diversified energy governance system, while international regulatory frameworks also include regional regulatory initiatives.

${ }^{15}$ While this proposed model takes its bearing from the dualist theory of international law and also advances the co-existence of municipal and international regulatory regimes, it does not align with the traditional feature of the dualist theory, which gives municipal law primacy in the case of conflict with international law. (See Edwin Borchard, "Relation Between International Law and Municipal Law" (1940) 27:2 Va L Rev 137. Rather, it delimits clear areas in which both systems can operate side-by-side, hence, obviating the possibility of a conflict. ${ }^{16}$ It has been argued that right to electricity should be subsumed under international human rights. Indeed, the African Commission on Human Rights in a case brought against the Zaire government (now, the Democratic Republic of Congo), held the Zaire government liable for failing to provide 'basic services' including electricity. See Communications 25/89 - 47/90-56/91-100/93: Free Legal Assistance Group, Lawyers' Committee for Human Rights, Union Interafricaine des Droits de I'Homme, Les Temoins de Jehovah/DRC, online: African Commission on Human and Peoples' Rights <http://www.achpr.org/files/sessions/18th/comunications/25.89-47.90-56.91100.93/achpr18_25.89_47.90_56.91_100.93_eng.pdf> The South African Constitutional Court has also found in favour of claimants who complained of lack of access to various utilities including electricity. See Government of the Republic of South Africa \& Ors. v. Grootboom \& Ors [2000] 11 B Const LR 1169. The United National Sustainable Energy For All (SE4ALL) programme also exemplifies the increasingly international dimension the issue of energy is taking.

${ }^{17}$ Like the climate/atmosphere, the ocean is one and the same world over. Despite this geophysical reality, countries have legal sovereign claims over the entire physical construct of their territories, inclusive of their territorial sea, internal waters, land and the airspace. See generally Article 2 (1)(2) of 1982 UNCLOS which provides that "The sovereignty of a coastal State extends, beyond its land territory and internal waters and, in the
} 
must, of necessity, be structured to cohere with the characteristics of the constituting elements of offshore renewables (renewable energy, the ocean and climate).

As noted above, literature on the regulatory framework of offshore renewables generally take a State-based or international approach. It is also not unlikely that such scholarly materials are focused on specific forms of offshore renewables. For instance, John Kindt ${ }^{18}$ and Michael Reisman ${ }^{19}$ concentrated on Ocean Thermal Energy Conversion (OTEC) generally from an international law of the sea perspective, reviewing whether the law of the sea contains sufficient provisions to regulate OTEC. On the other hand, Karen Scott ${ }^{20}$ and Meinhard Doelle, et $a l,{ }^{21}$ focus on wind energy and tidal energy respectively, taking a national/sub-national approach. ${ }^{22}$ Rather than the specific 'offshore renewable' option approach, it is also not uncommon to find scholars considering the concept of offshore renewables holistically either from an international or State-based perspective. ${ }^{23}$ The approach adopted in this paper is to consider 'offshore renewables' as a 'single concept'. While it is agreed that various offshore renewables have their distinct technical features, some of which will be considered shortly, my view is that ORE options are generally subject to substantially similar legal and regulatory concerns and challenges. This point is better illustrated by the fact that, irrespective of the approach taken in the literature afore referenced, the issues of maritime zones, navigation, fishery and pollution have been considered by all the authors to varying degrees. Each of these issues will be considered subsequently.

Of relevance to this paper are the works of Martin Tsamenyi and Max Herriman, ${ }^{24}$ Richard Barnes $^{25}$ and Yoshifumi Tanaka. ${ }^{26}$ Although fundamentally dissimilar in thrust, these scholarly works, to different extents, help lay the theoretical basis for my analysis and observations. Tsamenyi and Herriman argue that since the 1982 UNCLOS failed to "provide for the equitable and efficient utilization of ocean energy resources", an ocean energy protocol to UNCLOS, akin to the 1994 Agreement Relating to the Implementation of Part XI of UNCLOS and 1995 Agreement on Straddling Fish Stocks and Highly

case of an archipelagic State, its archipelagic waters, to an adjacent belt of sea, described as the territorial sea ... This sovereignty extends to the air space over the territorial sea as well as to its bed and subsoil".

18 John Warren Kindt, "Ocean Thermal Energy Conversion” (1984) 14:1 Ga J Intl \& Comp L 1 - 27.

${ }^{19}$ Michael Reisman, "Key International Legal Issues with Regard to Ocean Thermal Energy Conversion Systems" (1981) Faculty Scholarship Series 425 - 444.

${ }^{20}$ Karen N. Scott, "Tilting at Offshore Windmills: Regulating Wind Farm Development within the Renewable Energy Zone" (2006) 18 - 1 J Envtl L 89 - 118.

${ }^{21}$ Meinhard Doelle, et al, "The Regulation of Tidal Energy Development off Nova Scotia: Navigating Foggy Waters" (2006) 55 UNBLJ $27-70$.

${ }^{22}$ While Karen Scott considered the offshore wind energy regime in the United Kingdom, Meinhard Doelle et al (consistent with Canada's decentralized energy governance structure) restricted their work to tidal power in Nova Scotia (one of the ten provinces in Canada).

${ }^{23}$ For the international perspective, see Francesca Galea, "Legal Regime for the Exploration and Exploitation of Offshore Renewable Energy" (2011) Ocean Year Book_101 - 130; for the domestic perspective, see Sara Mahaney and Daniel Watt, "Charting a Course for a Good Governance of Canada's Emerging Ocean Economy" (2017) 61 Occasional Paper Canadian Institute of Resources Law $1-51$.

${ }^{24}$ Martin Tsamenyi \& Max Herriman, "Ocean Energy and the Law of the Sea: The Need for a Protocol" (1998) 29:1 Ocean Dev \& Intl L 3 - 19.

${ }^{25}$ Supra note 13.

${ }^{26}$ Yoshifumi Tanaka, A Dual Approach to Ocean Governance - The Cases of Zonal and Integrated Management in International Law of the Sea (Surrey: Ashgate, 2008), 
Migratory Fish Stocks, should be adopted. ${ }^{27}$ While not explicitly mentioning or canvassing a dualist approach to ORE governance, Tsamenyi and Herriman tangentially touch on the concept by conceptualizing their proposed Protocol as potentially affording "the energy industry and national governments an opportunity to look ahead and develop guidelines, which are conducive to their respective requirements and which protect the marine environment". ${ }^{28}$ No doubt, the protocol proposed by Tsamenyi and Herriman aligns with the 'international limb' of the dual approach to be developed in the latter part of this paper. However, the authors are quiet on the essential components of the proposed protocol and how it should operate.

Although Richard Barnes, like Tsamenyi and Herriman favoured an international approach to the management of ORE, he approached the subject matter from a theoretical perspective, drawing from theories of property to make a case for what he called "a more nuanced approach to energy sovereignty". ${ }^{29}$ He refers, inter alia, to the "fungible, nonexclusive and intangible" attributes of renewable energy, ${ }^{30}$ the location of such energy in marine zones (eg, Exclusive Economic Zone) ${ }^{31}$ and state of technology, ${ }^{32}$ as grounds to argue that the traditional natural rights conception of energy sovereignty must give way to a more cooperative and inclusive approach to ORE use and management. ${ }^{33}$ Notably, Barnes' work (inadvertently) makes up for the gap earlier identified in Tsamenyi and Herriman's work by suggesting what a potential protocol on offshore renewables could entail. This can be inferred from the six roles Barnes identified can be played by international law in 'energy regulation': provision of a framework on how 'transboundary or common resources are to be utilised"; prevention of State interference in energy production activities; facilitation of access to and supply of energy resources; provision of a framework to control transboundary consequences of energy use; coordination of responses to global challenges; and coordination of domestic energy law regimes and policies. ${ }^{34}$ In making a case for a common approach to offshore energy, Barnes failed to consider the role that must be played by States by the same token of the nature of energy and the spatial delineation of the oceans.

Unlike Barnes' somewhat unidirectional approach, Tanaka proposed a 'dual approach to ocean governance'. ${ }^{35}$ This approach, according to him, will entail:

.... a dual legal system between the zonal and integrated management approaches.

On the one hand, there is no doubt that the world is divided into sovereign States, the main role of the zonal management approach - spatial distribution of national jurisdiction - will in no way lose its importance. On the other hand, as will be seen, it is becoming apparent that the zonal management approach is insufficient for ocean management in some respects, and, thus, the new integrated

\footnotetext{
${ }^{27}$ Supra note 24 at $11-12$. The authors further argue that rather than seek an amendment of UNCLOS given the complexity potentially involved in such process, a Protocol is more likely to be entered into by State parties.

${ }^{28}$ Supra note 24 at 4.

${ }^{29}$ Supra note 13 at 14 .

${ }^{30}$ Supra note 13 at 16 .

${ }^{31}$ Supra note 13 at 18 .

${ }^{32}$ Supra note 13 at 19.

${ }^{33}$ Supra note 13 at 39.

${ }^{34}$ Supra note 13 at 28.

${ }^{35}$ Supra note 26 at $21-25$.
} 
management approach is needed in international law of the sea. Hence, two different approaches must co-exist in international law of the sea at the same time. Indeed, the purpose of the integrated management approach is not to replace the zonal management approach, but to resolve the problems that cannot be resolved under the zonal management approach. ${ }^{36}$

What is clear from Tanaka's proposal is the intention to balance the relationship between the sovereign rights of States over territories and the need for a cooperative use of ocean based resources, as against Barnes' seeming discountenancing of what Tanaka termed the 'zonal management approach'. ${ }^{37}$ To advance the dual ocean governance concept, Tanaka broadly applied it to the conservation of marine living resources, ${ }^{38}$ marine biological diversity ${ }^{39}$ and marine scientific research. ${ }^{40}$ However, he did not apply the approach to offshore renewables. An attempt will be made in this work to reconcile and adapt some of the findings made by Tsamenyi and Herriman, Barnes and Tanaka ${ }^{41}$ to the proposed dualist offshore renewables governance approach considered herein.

\section{AN OVERVIEW OF OFFSHORE RENEWABLE ENERGY TRENDS}

ORE is not a recent trend. ${ }^{42}$ However, as earlier noted, there is an increasing recourse to it. While onshore renewable energy sources can generally be limited to solar energy, wind energy and biomass, the ocean has multiple offerings. Charlier and Frankl listed these to include tidal power, marine winds, wave power, ocean thermal energy conversion, marine biomass conversion, marine currents, tidal currents, salinity gradients and hydrogen power. ${ }^{43}$ Although an in-depth assessment of the technical details of these renewable sources of energy is outside the scope of this paper, modern trends in the ORE enterprise will be considered to provide a proper context for the contentions made here. These

\footnotetext{
${ }^{36}$ Supra note 26 at 25.

37 As noted by Tanaka, scholars like Georges Scelle have argued for the treatment of the ocean as a 'domaine public international' since "it is impossible to find a natural limit between the territorial waters and the high seas". Again, D. Ruzie focusing "on the common interest in spaces" argued that all spaces of the oceans (including the internal waters) should be managed independent of territorial sovereignty. See supra note 26 at $9-12$. These viewpoints bare similarities with Barnes' argument. However, tallying with Tanaka's position and the thesis that will be advanced herein is the conception of 'domaine public international' by Nguyen Quoc Dinh, "Droit international public" (1975) 1 LGDJ 525 (cited by Tanaka supra note 26 at 12), who recognised the territorial sovereignty of a State, as well as the general interest covered by domaine public international.

38 Supra note 26 at $31-121$.

${ }^{39}$ Supra note 26 at $125-206$.

${ }^{40}$ Supra note 26 at $209-238$.

${ }^{41}$ In his findings, Tanaka identified five elements in support of an integrated management approach - sustainable development, ecosystem approach, precautionary approach, international supervision through international institutions and non-State enforcement. See supra note 26 at 240.

${ }^{42}$ For example, Charlier and Finkl traced tide mills to as far back as the $10^{\text {th }}$ century when it was first mentioned by Arab geographer, Al-Magdisi Shams al-Din; while they also stated that the first major hydroelectric plant in Rance River, Brittany, France, was operationalized in 1967, with same generating 540,000 kilowatt (Kw) of electrical power. See Roger H. Charlier \& Charles W. Finkl, Ocean Energy: Tide and Tidal Power (Berlin: Springer, 2009) 3.

${ }^{43}$ Ibid at $2-17$. This list is however by no means exhaustive, as solar energy which has somewhat been construed as an onshore energy source, is now been taken offshore with the development of offshore solar farms. See "offshore solar farms" (updated July 28, 2017) online: <https://www.greenmatch.co.uk/blog/2015/01/offshoresolar-farms $>$ However, as noted by Charlier and Frankl, most of these offshore renewable energy options (eg, marine currents, salinity gradients and hydrogen power) are more of "engineers' dreams", while others like OTEC are presently economically unattractive. See Ibid at 1 .
} 
assumptions include the following: considering the diverse and abundant renewable options in the ocean, there is bound to be an upsurge in such offshore ventures; the diverse ocean energy options are well placed to become primary sources of renewable energy; as such ventures increase and energy harvesting technologies advance, ORE enterprises will be taken farther offshore into the exclusive economic zone and the High Seas. For these reasons, some advancements in offshore renewable technologies, examples of policies adopted by States and regional bodies and the ORE potentials of Nigeria qua West Africa will be appraised in this section.

As hinted above, the phrase 'offshore renewable energy' does not refer to a single form of renewable energy. It consists of a bouquet of different forms of energy, and different countries and regions have comparative advantages over others in respect of the varying forms of energy. For example, while Australia, Canada, Norway, New Zealand and the United Kingdom have some of the highest offshore wind potential in the world; ${ }^{44}$ Canada (Nova Scotia), the United Kingdom and France are considered as countries with ideal tidal energy sites; ${ }^{45}$ and Nigeria and various Small Islands Developing States (SIDS) in the Pacific are among coastal States with the most substantial potentials for OTEC. ${ }^{46}$ The development and exploitation of ORE have however been largely informed by resource potential and financial/technological capacity. ${ }^{47}$ Although the present spread of offshore renewables, especially offshore wind and tidal energy, is entirely concentrated in developed countries, ${ }^{48}$ the current generated energy pales considerably to the actual potentials of these ORE sources. ${ }^{49}$ The low exploitation of ORE is largely attributable to the expensive and economically unattractive nature of such ventures, compared to more traditional onshore

\footnotetext{
${ }^{44}$ The above listed countries are assessed to have 5,448 Gigawatts (GW); 4,884.4 GW; 3,634.8 GW; 3422.7 GW and $2473 \mathrm{GW}$ of potential wind energy respectively. See Douglas Arent et al, Improved Offshore Wind Resource Assessment in Global Climate Stabilization Scenarios (Colorado: NREL, 2012).

45 World Energy Council, "World Energy Resources - Marine Energy", online: <https://www.worldenergy.org/wp-content/uploads/2017/03/WEResources_Marine_2016.pdf>

${ }^{46}$ Luis Vega, "Economics of Ocean Thermal Energy Conversion (OTEC)" (1992) American Society of Civil Engineers $152-181$.

${ }^{47}$ Eg., the abundance of wind energy and availability of financial wherewithal and technological knowhow are instrumental to the development of wind energy in the United Kingdom, which is reputed to have the "largest offshore wind market" with $36 \%$ of the global installed capacity as at 2016 (approximately 5,178 MW out of the total global installed offshore wind power capacity). See Global Wind Energy Council, "offshore wind power", online: (2016) <http://gwec.net/global-figures/global-offshore/>. Contrariwise, despite the huge potentials for OTEC in countries like Nigeria, Ghana, Ivory Coast, same is undeveloped, arguably as such countries have neither the technological capacity and/or financial ability to develop same.

${ }^{48}$ According to the Global Wind Energy Council, as at the end of 2016, approximately $88 \%$ of global offshore wind installations were in Europe, with the remaining 12\% located in China, Japan, South Korea and the United States. See Global Wind Energy Council, Ibid. The London Array, with 175 wind turbines, generating 650MW of electricity enough for about half a million homes in the United Kingdom, is the world's largest offshore wind energy farm, covering an offshore area of about $100 \mathrm{~km}^{2}$. See London Array, "The Project" online: <http://www.londonarray.com/the-project-3/>

49 To illustrate this, while the total energy consumed in 2015 is put at 17.4 Terrawatts (TW), the tidal energy potentials of Europe alone (106 identified locations) is put at $48 \mathrm{TWh} / \mathrm{yr}$, global wind energy is potentially 74.17TWh/yr and "the total potential global OTEC energy resources that could be extracted" sustainably is put between 30 and 90 Petawatts (PWh). See generally, Brian Seger, "Global Energy Consumption: The Numbers for Now and in the Future" (2016) Technical Information Center of Denmark. <http://orbit.dtu.dk/files/128048208/Global_Energy_Consumption_The_Numbers_for_Now_and_in_the_Future .pdf >; World Energy Council, supra note 45 at 9, 12 and NREL, supra note 44 at 24.
} 
renewables like wind, solar and biomass. ${ }^{50}$ The second reason often adduced for the nondevelopment of offshore renewables is distance to existing grids onshore. ${ }^{51}$ However, these narratives are already changing, and perhaps there is no better illustration of this than recent trends in the offshore wind energy industry.

Since 1991, when the first offshore wind farm was installed in Vindeby, Denmark, energy generated from offshore wind has grown from $4.95 \mathrm{MW}^{52}$ to $12,631 \mathrm{MW}$ in $2016 .{ }^{53}$ Underscoring the vast improvement in offshore wind technology vis-à-vis the drop in capital cost is the first floating offshore wind farm - the Hywind floating wind farm. Commissioned October 2017, Hywind generates 30 MW (6MW from each of 5 turbines), which can be used in "depths up to 800 metres". ${ }^{54}$ Another positive from the Hywind project is the projection by the developer of a reduction of the cost in energy from $€ 40$ to $€ 60$ per megawatt-hour (MWh) by $2030 .{ }^{55}$ This projection is put in a more immediate context by the Global Wind Energy Council. In its 2016 report, it stated:

...The big story in 2016 was the dramatic reduction in offshore wind prices. It started with the Dutch tender for Borssele $1 \& 2$ in June coming in at $€ 72 / \mathrm{MWh}$, well below expectations; followed by a Danish nearshore tender in September at $€ 64 / \mathrm{MWh}$. This was followed in November with the winning bid for the Danish Krieger's Flak project coming in at an astonishing €49.90/MWh; and then Borssele $3 \& 4$ in the Netherlands coming in at $€ 54.50 / \mathrm{MWh}$ in December. We now have the strange situation where at least at the moment, in some circumstances, offshore is cheaper than onshore! $!^{56}$

Besides the drop in the cost of offshore wind energy is the development of turbines which can be deployed farther in the EEZ, located in greater water depth and the improved capacity of the turbines. ${ }^{57}$ All these indicate that the phase of an increased exploitation of

\footnotetext{
${ }^{50}$ Charlier \& Finkl, supra note 42 at 1.

${ }^{51}$ Karen Scott stated this point in respect of offshore wind thus - "...costs associated with the offshore industry are substantially higher than for onshore wind turbines. The marginalisation of turbines adds approximately $10 \%$ to the cost of installation, and grid connection is around $25 \%$ higher for offshore projects. Maintenance ... and other associated costs ... are also much higher than the equivalent onshore costs. Thus, the economic viability of offshore wind farms is dependent upon the more favourable wind conditions that are generally present off the coast." Supra note 20 at 91 . Other identified challenges include - competing multiple marine spatial uses with "traditional navigation, fisheries and the laying and maintenance of transmission and communications cables", complex "interdisciplinary engineering and cooperative design expertise" and environmental concerns. See Mahaney and Daniel Watt, supra note, 23 at 5.

${ }^{52}$ World Energy Council, "World Energy Resources - Wind", online: (2016) <https://www.worldenergy.org/wpcontent/uploads/2017/03/WEResources_Wind_2016.pdf>

${ }^{53}$ Arent, supra note 44

${ }^{54}$ See Anna Hirtenstein, "The World's first floating offshore wind farm begins operating”, National Post (18 October 2017), online: <http://nationalpost.com/news/world/the-worlds-first-floating-offshore-wind-farmbegins-operating > and "The World's first floating wind farm commissioned in Scotland" CLIMATEACTION (18 October 2017), online: <http://www.climateactionprogramme.org/news/the-worlds-first-floating-wind-farmcommissioned-in>

${ }^{55}$ Ibid.

${ }^{56}$ GWEC attributed the reason for this drop to reasons such as "the maturing of the industry, the improvement and maturation of the technology and management thereof, growing investor and the introduction and deployment of a new generation of 6-8MW (and now $9 \mathrm{MW}$ with the up-rating of the Vestas V-164) machines, with enormous swept area and tremendous output". See GWEC, "Offshore Wind" online: (2016) <http://www.gwec.net/wpcontent/uploads/2017/05/Global-Offshore-2016-and-Beyond.pdf>

${ }^{57}$ Before the development of advanced offshore turbines like those used in the Hywind project, the farthest offshore turbines could be sited was in waters 50 metres deep considering that the foundation (whether monopile
} 
offshore renewables in the EEZ and the High Seas, is fast dawning on the world. This is not all. The advantages of offshore renewables, when compared with onshore options like solar, wind and biomass, also explain why there will be a further push offshore. Take offshore wind for example. A 2017 study confirms that "wind speeds over open ocean areas are often higher than those in the windiest areas over land". ${ }^{58}$ Further, the immense space available offshore, ${ }^{59}$ siting away from the public (to forestall agitations like the Not-In-MyBackyard campaign), non-encroachment on private property rights and the release of limited land spaces to other purposes, are additional positives which make offshore renewables worthwhile. ${ }^{60}$ One of the downsides of onshore renewables is that they vary according to the weather, hence lacking stability; OTEC is however said to "provide electricity on a continuous (non-intermittent) basis ... provides cooling without electricity", and has a $90 \%-95 \%$ capacity, one of the highest of power generation capacity. ${ }^{61}$ Like offshore wind, OTEC is most suitable deep offshore, as it is dependent on the "temperature difference between warm seawater at the surface of the ocean, and cold seawater at between 800 - 1000 metres depth". ${ }^{6}$

From the above, it is not surprising that developed countries are increasingly gravitating towards offshore renewables, investing in same and enacting legislations qua policies to regulate them. Europe, which hosts $88 \%$ of the world's offshore wind installations, offers an example of the evolving regulatory template of offshore renewables. Offshore wind energy in Europe is regulated nationally. This State-based governance structure was tacitly endorsed by the Court of Justice of the European Union (CJEU) in Alands Vindkraft AB v Energimyndigheten (Alands). ${ }^{63}$ In Alands, the Swedish Energy Agency (respondent) refused to authorize, "for the purposes of the award of electricity certificates, a wind farm in Finland operated by Alands Vindkraft". ${ }^{64}$ The CJEU held that EU's Directive 2009/28

or jacket) needs to be fixed-bottom. The development of floating foundations, like used in the Hywind project, however does away with the need for such fixed bottom foundations (variants of floating turbines include - sparbuoys, spar-submersible and tension leg platform, with the spar-buoy being the most appropriate for waters deeper than 100metres). See International Renewable Energy Agency, "Floating Foundations: A Game Changer for Offshore Wind Energy", $\quad$ online: $\quad$ (2016) <http://www.irena.org/DocumentDownloads/Publications/IRENA_Offshore_Wind_Floating_Foundations 2016 .pdf>. The Hywind turbines for example can be used in waters 800 metres deep, making same potentially useful farther into the 200NM EEZ, and (prospectively, the High Sea). As $80 \%$ of offshore wind resources are said to be in deep waters, there is bound to be further push offshore for the harvesting of wind energy and other forms of renewables. See Anna Hirtenstein, supra note 54.

${ }^{58}$ Anna Possner \& Ken Caldeira, "Geophysical Potential for Wind Energy over the Open Oceans”, online: (2017) Proceedings of the Academy of $\quad$ Sciences 1 <http://www.pnas.org/content/early/2017/10/03/1705710114.full.pdf >.

${ }^{59}$ The ocean is said to be $72 \%$ of the earth's surface, covering about 140 million square miles. See "Factsheet: People and Oceans" < http://www.un.org/sustainabledevelopment/wp-content/uploads/2017/05/Ocean-factsheet-package.pdf $>$ possner and Caldeira also pointed out that "the amount electricity generated per turbine decreases as the turbine density and geographical area of the wind farm increases. As KE (Kinetic Energy) is extracted, the mean flow wind speed is reduced". See Anna Possner and Ken Caldeira, Ibid. There is a limit to how much wind farms can be spread onshore, considering the more limited space.

${ }^{60}$ See generally Sara Mahaney and Daniel Watt, supra note 23 at 5.

61 IRENA, "Ocean Thermal Energy Conversion - Technology Brief" online:

<http://www.irena.org/DocumentDownloads/Publications/Ocean_Thermal_Energy_V4_web.pdf>

62 Ibid at 3.

${ }^{63}$ C-573/12, [2014] All ER (D) 13 (Jul).

${ }^{64}$ Ibid 
allows the territorial limitation of the award of certificates and left it to countries (in this case, Sweden) to make legislations providing for the award of tradable certificates to producers of green electricity. ${ }^{65}$ Germany's Offshore Wind Energy Act, 2017 (OWEA) is an example of the efforts of European nations to provide State-based legislative and regulatory frameworks for offshore wind. Further lending credence to the assumption made earlier on the potential increase in offshore renewables, the aim of OWEA "is to increase the installed capacity of offshore wind energy installations to a total of $15 \mathrm{GW}(15,000$ MW) between 2021 and 2030". ${ }^{66}$ The OWEA is considered more closely below.

It must, however, be pointed out that the most explored offshore renewable is not as much a function of potential, as it is of location and capacity. For example, OTEC is said to have the highest potential among all ocean energy technologies, ${ }^{67}$ but it is about the least developed. The reason might not be unconnected with the fact that the most suitable locations for OTEC are offshore developing or underdeveloped countries. ${ }^{6}$ On the converse, as shown above, developed countries are offshore wind/tidal energy rich; they therefore naturally invest more in these potentials. Taken further, it is arguable that the level of research and technological development will largely be dependent on the location of an offshore resource. Thus, though OTEC projects can be traced back to the $1970 \mathrm{~s},{ }^{69}$ there has not been much advancement in the technologies necessary for its harvesting. ${ }^{70}$ Like many other developing countries in Africa and SIDS, Nigeria's coastal zones, particularly the EEZ, is highly suitable for OTEC. ${ }^{71}$ The necessity of the development and deployment of this technology in countries like Nigeria is even more compelling considering the acute energy poverty they suffer. Nigeria, for example, barely generates a total of $3500 \mathrm{MW}$ for

65 The European Union however through Directive 2014/89/EU established a framework for maritime spatial planning. The Directive however only provides a framework, and does not affect the competence of member States to "design and determine, within their marine waters, the extent and coverage of their maritime spatial plans". See Directive 2014/89/EU of the European Parliament and of the Council of 23 July 2014 establishing a framework for maritime spatial planning, [2014] OJ, L 257/135 at art 2.

${ }^{66}$ Offshore Wind Energy Act 2017 (Germany), s 1(2). Germany's Renewable Energy Sources Act, 2017 (RESA) also contains provisions governing offshore wind. S 2(1)(a) of RESA projects offshore wind installed capacity of 6500MW in 2020.

${ }^{67}$ IRENA, supra note 61 at 4

${ }^{68}$ About 98 countries are identified to be OTEC rich. Many of these countries are countries in Africa and island nations around the Pacific/Indian oceans. See IRENA, supra note 61 at 16 and Luis Vega, supra note 46.

${ }^{69}$ IRENA, supra note 61 at 5

${ }^{70}$ This however does not mean that there are no other constricting factors to investment in OTEC projects, like its high capital cost. However (subject to other variables), while an $8000 \mathrm{MW}$ tidal power plant on the Severn Estuary in the United Kingdom is estimated to cost US\$ 15 billion (approximately US\$1.87 Million per MW) (see "Tidal Energy", Renewable Energy Development, online: <http://renewableenergydev.com/tidal-energy/>), a 50MW OTEC plant has been proposed at US\$75 Million (approximately US\$1.5 Million per MW). This should be compared to the Open-Centre underwater wind turbine at the Bay of Fundy, which generates 2MW of electricity at the cost of $\$ 30$ million (including the cost of a second turbine). See "Nova Scotia just fulfilled its longstanding dream to harness the tides with an underwater windmill", Financial Post (25 November 2016) online: $<$ http://business.financialpost.com/commodities/energy/nova-scotia-just-fulfilled-its-longstanding-dream-to-

harness-the-tides-with-an-underwater-windmill >. It is worthy of note that, by-products like, production of fresh water and the removal of undersea nutrient, making same more accessible to marine species are advantages possessed by OTEC over other offshore renewables. See Ocean Thermal Energy Conversion, online: <http://www.esru.strath.ac.uk/EandE/Web_sites/98-9/offshore/otec.htm>.

${ }^{71}$ While Nigeria is proven to have abundant OTEC capacity, (see Luis Vega, supra note 46) the NREL records that it has no significant offshore wind energy potential within its coastal zones. See Douglas Arent, supra note 44 at 22 . 
its over 170 million population. This is more poignant when compared to the 140,000 MW installed electricity generation capacity for Canada's approximately 35 million population as at $2014 .^{72}$ Although masked as a national problem, a situation like Nigeria's cannot be divorced from its international context. The context of an obligation under the Paris Agreement which impels Nigeria to contribute to the protection and sustenance of a common environment, hallmarks this global link. Hence, it is obligated to 'balance' its enormous energy deficit sustainably and responsibly.

Deducible from the above overview are some salient features of global offshore renewables and the ORE industry, to wit: ORE options can provide sustainable civilization-scale energy; they are diverse; they are location specific; capacity and location determine the level of investment in and development of an ORE potential; offshore renewables possess substantial advantages over their onshore counterparts; there is increasing gravitation of offshore renewable projects (particularly offshore wind) farther into the oceans; ORE options are fungible; ${ }^{73}$ and developed countries have largely adopted a State-based approach to offshore renewable energy governance.

The next section justifies the need for a dualist approach to ORE governance. It does this by placing the trend considered above under the lens of Arvid Pardo's advocacy for the treatment of the ocean space as an ecological whole.

\section{OFFSHORE RENEWABLES: CONTEMPORIZING THE PARDO ARGUMENT}

At the foundation of the international law of the sea is the debate on whether the world's ocean should be treated as mare clausum (closed sea) where only a handful of coastal States will have control it, or mare liberum, entailing the freedom of all States to access and use the ocean. ${ }^{74}$ Although it has been suggested that the mare liberum eventually "prevailed and freedom of the seas became the doctrine of the time", ${ }^{75}$ the present law of the sea regime as represented by the 1982 UNCLOS is essentially a product of the concern of developing countries that although 'technically open', the ocean under the pre-1982 UNCLOS res nullius regime was constructively closed. ${ }^{76}$ This 'constructive closure' of the ocean was at the core of Arvid Pardo's several representations to the United Nations, representations that

\footnotetext{
72 National Energy Board, "Fact Sheet - Canada's Energy Future 2016: Energy Supply and Demand Projections to 2040 - Electricity Highlights" (2016) online: <https://www.neb-one.gc.ca/nrg/ntgrtd/ftr/2016/fslctrcteng.html>

${ }^{73}$ Barnes, supra note 13 at 16.

${ }^{74}$ See generally Robin Churchill \& Vaughan Lowe, The Law of the Sea, 2nd ed (Manchester: Manchester University Press, 1988) at 3 - 4. In what has now been christened the 'battle of the books', Hugo Grotius made a compelling case for an open sea regime in his 1609 work 'mare liberum', while in response John Selden published a counter work 'mare clausum' in 1635. See Donald Rothwell \& Tim Stephens, The International Law of the Sea, 2nd ed (Oxford; HART Publishing, 2016) 3.

${ }^{75}$ See Donald Rothwell \& Tim Stephens, Ibid.

${ }^{76}$ Commenting on the need for the need for the res nullius concept to be replaced with a res communis ideal, Yong-Ok Park asserted thus - "The concept of common heritage of mankind is based on the two premises that no State should acquire more than its equitable share of the resources ... and that the world community should be entitled to take such steps as might be necessary to ensure such an equitable sharing..." Such ideas may be acceptable to the underdeveloped, weak and underprivileged nations, but unacceptable to the developed, strong and privileged 'great powers'... Yong Ok-Park, "Res Communis versus Res Nullius" (1976) 5:1 Journal of East and West Studies 77 at $80-81$.
} 
are lauded as the catalyst for the present law of the sea regime. But is the present law of the sea regime adequate to cater for offshore renewables? Are established legal regimes on fishery, maritime and/or offshore mining appropriate for offshore renewable governance? Is there a possibility for a repeat of the concerns expressed by Arvid Pardo on creeping jurisdiction and inequitable exploitation of renewables from the ocean? Some of these questions are considered in detail hereunder.

\subsection{PARDO'S ARGUMENT}

The law of the sea, as it is today, reflects the advocacy of Arvid Pardo. On the flip side, Pardo's views on the subject were largely shaped by the economic and geographical status of his country, Malta. Malta, in Pardo's words, was a "country struggling to break free of the tentacles of poverty", and a small island State. ${ }^{77}$ This is the context in which Pardo delivered his seminal 1967 address to the United Nations and recommended five principles for the governance of the sea bed: the non-appropriation of the seabed and ocean floor beyond "the limits of national jurisdiction" by countries; exclusive reservation of the seabed for peaceful purposes; permissibility of non-defence linked scientific research in the deep seas and ocean floor; exploitation of resources in the said seabed for the interest of mankind, particularly poor countries; and exploitation of seabed consistently with the principles of the United Nations Charter without obstructing the High Sea or impairing the marine environment. ${ }^{78}$ Beyond Malta's geographical and economic status, other factors that influenced Pardo's argument included technological development and scientific research, creeping jurisdiction, multiple use of ocean space, environmental concerns and the militarization of the oceans. More pointedly, on the interrelatedness of technology, energy and ocean space, Pardo stated:

Ocean space contains immense resources, the development of which will have an impact on the world economic system ... It is clear that these States which either do not have access to the technology for exploiting the resources of their seas will be at a grave disadvantage in the battle for economic survival. New forms of energy production, now clearly foreseeable, will lead in the near future to what I will call the industrialization of the ocean space; this will aggravate the disadvantage of those which do not have the appropriate technology. ${ }^{79}$

As shown in part III of this work, Pardo's forecast on 'the industrialization of the ocean space' in respect of ORE, has already begun. To arrest the trend of creeping jurisdiction and facilitate the equitable and sustainable use of the oceans, Pardo suggested what he called "a new legal

\footnotetext{
${ }^{77}$ In his speech to the plenary of the General Assembly in 1968, Arvid Pardo stated thus - "I venture today to put before this Assembly certain considerations which are of particular importance to my country and, I think, also to others which, like Malta, are small, have to struggle to break free of the tentacles of poverty, or are militarily weak. The weaknesses we share in size, wealth, and power give us a natural interest in the work of the United Nations and spur us to efforts both within this organization and outside it ... to act in concert in search of peace and a wilder distribution of the wealth of this earth, within the framework of social justice and equity among nations". See Arvid Pardo, The Common Heritage - Selected Papers on Oceans and World Order 1967 - 1974 (Malta: Malta University Press, 1975) 43.

78 Ibid at $40-41$.

${ }^{79}$ Arvid Pardo, "Address to Subcommittee III of the Committee on the Peaceful Use of the Seabed and the Ocean Floor", July 20, 1973, supra note 75 at 301.
} 
principle", ${ }^{80}$ - "the common heritage" concept; which he described in his October 29, 1968, address thus:

The common heritage concept implies freedom of access and use on the part of those having part of the heritage, but also regulation of use for the purpose of conserving the heritage and avoiding infringement of the rights of others; inherent in regulation of use is, of course, responsibility for misuse. The concept finally implies equitable distribution of benefits from exploitation of the heritage. It is possible to go further; the notion of property that cannot be divided without the consent of all, and which should be administered in the interests and for the benefit of all, is a logical extension of the common heritage concept. ${ }^{81}$

While Pardo's earlier addresses pigeonholed the common heritage principle to the use of the seabed and ocean floor "beyond the limits of national jurisdiction", 82 he subsequently transitioned to advocating for a more robust application of the principle to "the ocean space as a whole", rather than as a stratified space. ${ }^{83}$ Relevant to this work are the following points canvassed by Pardo in support of what he termed "a new international order". ${ }^{84}$

i. $\quad$ From the polycentric use of land, sea and the air, man has capacity to irreparably damage the ocean space "which is a single ecological system vital to life on earth";

ii. Man has the technological capacity "to cause extreme changes in the natural state of the marine environment over vast areas from the site of his intervention";

iii. "Ocean space living resources are vast and renewable but they can be depleted in the absence of management";

iv. Unregulated large scale exploitation of ocean space mineral resources might seriously affect land producers;

v. 'Ocean space will be progressively used and exploited with increasing intensity and diversity in all its dimensions; consequently conflicts of use will become increasingly frequent in the absence of authority".

Consequently, Pardo proposed a dual marine governance construct made up of a 200 nautical mile area of national jurisdiction and an "ocean space beyond national jurisdiction" which will be wholly managed by international institutions. ${ }^{85}$

\footnotetext{
${ }^{80} \mathrm{Ibid}$ at 64.

${ }^{81} \mathrm{Ibid}$ at 65.

${ }^{82}$ As at 1967, by virtue of the Convention on the Territorial Sea and the Contiguous Zone 1958 and the Convention on the Continental Shelf, 1958, the "limits of national jurisdiction" were the territorial sea, contiguous zone and continental shelf of each country. The Exclusive Economic Zone is a creation of the 1982 UNCLOS.

${ }^{83}$ According to Pardo, the new international order would have two purposes - the safeguarding of the common interest of the international community; and "to make possible the full utilization of scientific and technological advance (sic) through a rational management of ocean space beyond national jurisdiction, and the equitable development of its resources for the benefit of all countries". Pardo, "Thirteenth Statement to the Committee on the Peaceful Uses of the Seabed and the Ocean Floor, March 23, 1971, supra note 77 at 194.

${ }^{84}$ Ibid at 202.

85 Ibid at $199-201$.
} 


\subsection{MAINSTREAMING PARDO'S ARGUMENT}

While Pardo's position on a dualist ocean governance structure was not adopted into the text of UNCLOS III, present realities, particularly in the more contemporary context of the growing global demand for energy; the imperatives of a sustainable environment; the increasing technological capacity of developed countries to harvest energy further ashore vis-à-vis the energy poverty of developing/underdeveloped countries; confer relevance and validity on his views. It is, indeed, arguable that Pardo made his arguments before the enactment of the 1982 UNCLOS. However, a cursory consideration of UNCLOS will show that the concerns expressed by Pardo still exist, and find evidentiary corroboration in the global ORE industry.

To start with, the multiple maritime zones which Pardo rightly stated as "nothing sacred", still serve as a foundational factor in ocean governance. The world ocean is presently generally split into the $12 \mathrm{NM}$ territorial sea, ${ }^{86}$ a $24 \mathrm{NM}$ contiguous zone, ${ }^{87} 200 \mathrm{NM}$ Exclusive Economic Zone, ${ }^{88} 200 \mathrm{NM}-350 \mathrm{NM}$ continental shelf ${ }^{89}$ and the High Sea. ${ }^{90}$ While UNCLOS provides for the exercise of sovereignty in the territorial sea, with other states having the right of innocent passage, ${ }^{91}$ it recognises sundry rights described severally as 'control', ${ }^{92}$ sovereign rights $^{93}$ and jurisdiction ${ }^{94}$. Overall, aside the more comprehensive rights (other than the right of innocent passage) available to a coastal State in respect of its territorial sea, the territorial sea, contiguous zone, the EEZ and continental shelf provide a coastal State with the exclusive rights to explore, exploit, conserve and manage natural resources. ${ }^{95}$ Particularly in respect of the EEZ, Article 56(1)(a) of UNCLOS provides for the exercise of the sovereign right of a coastal State "for the ... production of energy from the water, currents and winds". The interconnection of these zones, and the similarities in the rights and duties of both coastal and non-coastal States, question the necessity of the balkanization. This is more evident in the cosmetic line sought to be drawn between the EEZ and the continental shelf. Pardo described this kind of distinction as a fictitious legal line, as there is an indivisible unity between the ocean's "surface, water column, ocean floor and its subsoil". 96

Prior to the coming into force of its EEZ declaration in $2014,{ }^{97}$ the confusion that attended the United Kingdom's (UK) unilateral creation of a Renewable Energy Zone (REZ) was one of the offshoots of the present law of the sea regime. ${ }^{98}$ As noted elsewhere, under the present regime, while a continental shelf is a "natural prolongation" of a coastal State's land territory and,

\footnotetext{
${ }^{86}$ Article 3 of UNCLOS.

${ }^{87}$ Article 33(2) of UNCLOS.

${ }^{88}$ Article 57 of UNCLOS.

${ }^{89}$ Article 76 of UNCLOS.

${ }^{90}$ See generally Pt. VII of UNCLOS.

${ }^{91}$ See Article 17 of UNCLOS.

92 Article 33(1) of UNCLOS.

93 Articles 56(1)(a) and 77(1) of UNCLOS.

${ }^{94}$ A coastal State has the jurisdiction as regards the establishment and use of artificial islands, installations and structures; marine scientific research and protection and preservation of the marine environment in the EEZ. See Article 56(1)(b) of UNCLOS.

${ }^{95}$ In exercising the rights, UNCLOS mandates coastal States to "have due regard" and "act in a manner compatible with the provisions of this convention" (See for example Article 56(2)); The Convention also guarantees the rights of navigation, overflight, laying of submarine cables and pipelines.

96 Pardo, supra note 83 at 194.

${ }^{97}$ See The Exclusive Economic Zone Order 2013, SI 2013/3161.

${ }^{98}$ See Energy Act 2000 (UK), c 20, s 84.
} 
therefore, automatically accrues to it, an EEZ must be claimed before a coastal State can exercise sovereign rights and jurisdiction. ${ }^{99}$ It has also been noted that about 27 of the 152 coastal States in the world have not claimed an EEZ. Consequently, while these States can exercise Article 77 rights (on continental shelfs), they cannot lay claim to Article 56 rights (as per EEZ). It has, however, been argued that since Article 80 provides that "Article 60 applies mutatis mutandis" to the continental shelf, and Article 60(1)(b), on the other hand, referenced Article 56 which provides for rights in the EEZ, a separate declaration of an EEZ need not be made. ${ }^{100}$ But this is not a foolproof response to the contention. A closer look at Article 80 shows that Article 60 only applies to the extent that "artificial islands, installations and structures" are on the continental shelf. In other words, assuming same will apply at all, an offshore energy installation must be "on the continental shelf". Can the Hywind floating wind farm, a floating tidal buoy, a floating solar farm or a floating OTEC system be said to be "on the continental shelf'? To understand what the phrase "on the continental shelf" means, recourse could be had to Article 77(4), which delimits the sovereign right exercisable by a coastal State to the "mineral and other non-living resources of the seabed and subsoil together with living organisms". This puts 'extraction' of natural resource from the 'seabed and subsoil' at the core of the meaning of the phrase 'on the continental shelf'. This, generally, does not apply to ORE. As noted by Karen Scott, "such rights exercised by coastal States are not available under Part V of UNCLOS, which is confined to the EEZ". ${ }^{101}$ Scott, however, noted that the right to construct installations for offshore renewables can then be done under Article 87. ${ }^{102}$ The problem with this conclusion is that insofar as a country has not claimed an EEZ under UNCLOS, the zone becomes part of the High Seas, and Article 87(1) rights are "open to all States". Given the cogency of an argument against the legality of any zone other than a specifically declared EEZ (apart from the territorial sea and continental shelf), it is not surprising that the United Kingdom in 2014 eventually declared an EEZ.

The above analysis seeks to point out the needless complexity occasioned by the multiple maritime zones. Another point made by Pardo was on the depletable tendency of otherwise renewable 'ocean space living resources'. This position can also be extended to offshore renewables. Although many have construed the concept of 'renewability' to mean 'infinite availability', it has been proven that an unsustainable and inefficient use of a renewable energy source can deplete it. Richard Barnes, for example, stated that "in the case of sunlight and wind, the energy may be captured at fixed points and this takes energy out of the natural system". ${ }^{103}$ Indeed, Possner and Caldeira's 2017 study has affirmed that "wind farm cannot be treated as independent and that the amount of electricity generated per turbine decreases as the turbine density and geographical area of the wind farm increases". ${ }^{104}$ This is also applicable in varying degrees to other forms of offshore energy. This reality potentially necessitates the spread of renewable energy projects by individual countries, over different parts of the oceans, including the High Seas, to harvest optimal energy. However, more traditional uses of the ocean space,

\footnotetext{
${ }^{99}$ Rothwell \& Stephens, supra note 74 at 88.

${ }^{100}$ See Scott, supra note 20 at $94-96$.

${ }^{101}$ Ibid at 96.

102 Ibid.

${ }^{103}$ Supra note 13 at 16.

${ }^{104}$ Supra note 58 at 1.
} 
particularly fishery and maritime navigation, limit how spread-out ORE projects can be. This again puts offshore renewables in a finite context. Conversely, a more cooperative governance approach allows States to locate the best site for an ORE project, and jointly maximize its potential. $^{105}$

As repeatedly emphasised by Pardo, the question of equity is at the root of ocean governance. Whether allocating a $200 \mathrm{NM}$ EEZ to developing countries that lack the technical and financial capacity to exploit the resources therein satisfies this equity demand is, however, a question worth asking. ${ }^{106}$ In the context of offshore renewables, it has been shown that ORE projects are virtually entirely located offshore developed countries. This again affirms the earlier point made on 'constructive mare clausum'. Non-exercisable rights are as good as non-existent rights. Further, landlocked ${ }^{107}$ and geographically disadvantaged ${ }^{108}$ States are dealt a relatively unfair hand. It is important to note that these countries are some of the poorest in the world. ${ }^{109}$ Article 69 and Part X of UNCLOS guarantee landlocked States' rights to "participate ... in the exploitation of an appropriate part of the surplus of the living resources" in the EEZ and transit through coastal States in exercise of the freedoms recognised under UNCLOS. ${ }^{110}$ The explicit reference to 'living resources' in Article 69 effectively deprives landlocked countries access to ORE. ${ }^{111}$ The closest access landlocked countries have to "non-living resources" away from the High Seas is a share of payments made by a coastal State that exploits non-living resources beyond its $200 \mathrm{NM}$ continental shelf. ${ }^{112}$ Tsamenyi \& Herriman reinforce that, in the face of the dependence of landlocked (and developing) countries on "environmentally destructive fossil

\footnotetext{
${ }^{105}$ Ronan Long, in canvassing for a regional approach to offshore wind governance in the European Union, argued that such approach is more cost effective, improves the technical capacity of the sector, helps avoid and resolve conflicts, and reduces exposure to the volatility of international energy markets. See Ronan Long, "Harnessing Offshore Wind Energy: Legal Challenges and Policy Conundrums in the European Union" in Nigel Bankes \& Seline Trevisanut, eds, Energy from the Sea - An International Law Perspective on Ocean Energy (Boston: BRILL NIJHOFF, 2014) 152.

${ }^{106}$ In making this point, the point is not lost on the writer that the EEZ was substantially a product of the advocacy of developing countries, via its introduction by Kenya to the Asian-African Legal Consultative Committee in January 1971. But as noted by Churchill and Lowe, the move was informed by developing countries' apprehension that distant fishing capacity of developed countries will limit their fishing rights. See supra note 74 at 134.

${ }^{107}$ Article 124(1)(a) of UNCLOS defines a "land-locked State" as "a State which has no sea-coast". There are 43 landlocked countries in the world. See World Atlas, "Largest Landlocked Countries in the World", online: <http://www.worldatlas.com/articles/the-largest-landlocked-countries-in-the-world.html> 28 of these countries are in Africa and Asia. See United Nations Conference on Trade and Development, "Landlocked Developing Countries" online: <http://unctad.org/en/Pages/ALDC/Landlocked\%20Developing\%20Countries/UNrecognition-of-the-problems-of land-locked-developing-countries.aspx $>$.

108 Article 70(2) of UNCLOS defines "geographically disadvantaged States" as "States bordering enclosed or semi-enclosed seas, whose geographical situation makes them dependent upon the exploitation of the living resources of the (EEZ) of other States in the sub-region or region..." Article 70(2) - (6), in like manner as Article 69, provides for the rights and limitations of such States.

109 'The Economist' reported that "with a few exceptions, the world's ... landlocked countries are poor. Of the 15 lowest-ranking countries in the Human Development Index, eight have no coastline. All of these are in Africa". See "The Economics of Landlocked Countries - why it's better to have a coastline", The Economist (9 May 2015) online: 〈https://www.economist.com/news/americas/21650574-why-its-better-have-coastline-interiors>

110 See Article 125 of UNLOS.

${ }^{111}$ Geographically Disadvantaged Countries like Iraq and the Democratic Republic of Congo, depending on the type of ORE, could also be potentially deprived of benefiting from such, as Article 70 also refers to 'living resources'.

112 See Articles 84(1)(4) of UNCLOS.
} 
fuels", depriving them of the right to access offshore renewables is not only inequitable to these countries but ultimately disadvantageous to the world. ${ }^{113}$

The incongruity between Pardo's 'new international order' for the oceans and the current High Sea regime is evident. His comment on the 'fictitious legal line' again reflects in the current governance structure of the High Seas. ${ }^{114}$ As it is in the case of the EEZ and continental shelf, UNCLOS draws a line between the superjacent waters "beyond the limits of national jurisdiction" and the "seabed and ocean floor and subsoil thereof". ${ }^{115}$ Essentially, the High Seas combine the res nullius and res communis concepts. Whereas States have the freedom of navigation, overflight, to lay submarine cables and pipelines, to construct artificial islands and other installations, fishing and scientific research in/on the superjacent waters of the High Seas, ${ }^{116}$ the seabed, ocean floor and subsoil ('the Area') and the resources contained in them, are classified as "the common heritage of mankind". ${ }^{117}$ The Area and its resources are to be administered, for and on behalf of "mankind as a whole" by the International Seabed Authority (the Authority). ${ }^{118}$ Compared to the rights exercisable by coastal States in the EEZ, the clause 'exploitation and exploration of the zone, such as the production of energy from the water, currents and winds', is not explicitly included as one of the freedoms exercisable in the High Seas. Does this then imply that States cannot embark on ORE projects in the High Seas? This question has particularly dire implications for countries which have not declared the $200 \mathrm{NM}$ EEZ, as the waters outside their territorial sea automatically become part of the High Seas.

To validate the potential siting of an offshore energy project in the High Seas, arguments have been canvassed for a broad interpretation of Article 87(1)(d) to allow for the "freedom to construct artificial islands, and other installations". ${ }^{119}$ To justify this claim, emphasis is often placed on the clause in Article 87(1)(d) - "subject to Part VI". It has therefore been argued that Article 80 "which provides that "Article 60 applies mutatis mutandis to artificial islands, installations and structures on the continental shelf", operationalises Article 56 which authorises a coastal State's right to produce ORE. ${ }^{120}$ As shown earlier, Article 80 provides no justification for the siting of offshore renewable installations on the continental shelf. Therefore, it is doubtful if this argument is valid in respect of the High Seas. Further, interpreting Article 87(1)(d) as triggering Article 80, amounts to defining 'subject to' as an incorporation clause. On the contrary, the term 'subject to' is "used to assign a subordinate

\footnotetext{
${ }^{113}$ Supra note 24 at 10.

${ }^{114}$ High Seas are "all parts of the sea that are not included in the exclusive economic zone, in the territorial sea or in the internal waters of a State, or in the archipelagic waters of an archipelagic State". See Article 86 of UNCLOS. 115 See Article 1(1)(1) of UNCLOS.

${ }^{116}$ See Article 87(1) of UNCLOS.

${ }^{117}$ See Article 136 of UNCLOS.

${ }^{118}$ See generally Articles 137, 156 and 157 of UNCLOS.

119 Nicholas Lund argued that - “...the placement of renewable energy installations on the high seas can be justified under UNCLOS. The trail begins with Article 87(1)(d) ...” He however subsequently noted that Article 89 could be a roadblock to such offshore installations, since "unlike fisheries and deep seabed mining .... Which UNCLOS sets out specific regulations, renewable energy installations would permanently occupy certain areas of the High Seas". See Nicholas Lund, "Renewable Energy as a Catalyst for Changes on the High Seas Regime" (2010) 15:1 Ocean and Coastal Law Journal 95 at 108 - 109. With recently technological developments like floating wind turbines, Lund's argument on permanence of offshore installations does not appear to be a compelling argument against such projects.

${ }^{120}$ Ibid.
} 
position to an enactment, or to pave the way for qualifications". ${ }^{121}$ Hence, rather than incorporating Part VI, Article 87(1)(d) has been subordinated to the provisions of Part VI; and in the event of a conflict, Part VI will be given preference. The bottom line is that ORE cannot be brought under Article 87(1)(d) by referencing Part VI of UNCLOS.

A more compelling argument allowing for the siting of offshore renewable projects in the High Seas is predicated on the prefacing of the freedoms listed in Article 87(1) with the phrase 'inter alia' meaning "among other things". ${ }^{122}$ In effect, this allows the admission of other freedoms less the restrictions in UNCLOS, particularly, Part XI. ${ }^{123}$ It has, however, been suggested by Churchill and Lowe that there is "arguably, a presumption in favour of an established use as against a new use". ${ }^{124}$ In other words, in the event of a conflict between ORE and more established industries like maritime and fishery, the latter will have preference. Prospective offshore renewables constitute "a new use" of the High Sea. Hence, subject to the "due regard" proviso under Article 87(2), it appears that ORE projects can be undertaken by countries on the High Seas. But what is the implication of this conclusion for developing countries? Pardo's 'industrialization of the ocean space' concern is worth recalling. This implies that developed countries, with their increasingly advancing technologies, are well placed to 'colonize' the High Seas. It is again worth recalling that a concern similar to this informed the development of the ISA regime. Clearly, the underlying equity and fairness principles of the High Seas seem poised to be further eroded.

Although framed to apply to diverse issues pertaining to the oceans, Pardo's proposals provide workable suggestions on how an equitable and sustainable ORE governance regime can be developed. As noted above, Pardo advocated for a dual ocean structure - a 200 NM National Ocean Space and an International Ocean Space. Beyond thus:

...The coastal State should contribute to the international institutions a percentage of the revenue received from the exploitation of the living and non-living resources of ocean space beyond its jurisdiction ... The financial contribution from the revenue received from resource exploitation should be greatest in the zone adjacent to the international area $\ldots{ }^{125}$

Pardo suggested a contribution of $25 \%, 50 \%$ and $75 \%$ of revenue received by a coastal State if the resource exploitation is within $100-150$ miles, 150 - 175 miles and 175 miles - 200 miles from the country's shore. ${ }^{126}$ In the face of issues considered below, Pardo's proposal provides content for a dualist offshore energy governance structure that takes into consideration the sovereignty and sovereign rights of a coastal State over its territorial sea and EEZ, while factoring in the fungible nature of an offshore energy resource; unity of the eco-system; polycentric spatial use of the oceans; possibility of depletion and the equitable treatment of developing, geographically disadvantaged and landlocked States. His view that there should be

${ }^{121}$ Elmer Driedger, The Composition of Legislation Legislative Forms and Precedents (Ottawa; Supply and Services Canada, 1976) 139.

122 Black's Law Dictionary, 8th ed, sub verbo "inter alia".

${ }^{123}$ See Rothwell \& Stephens, supra note 74 at 164.

${ }^{124}$ See Churchill \& Lowe, supra note 74 at 166.

125 Supra note 83 at 219.

${ }^{126}$ Supra note 83 at 220. 
no charge for resources exploited between $0-100$ miles of ocean space protects the integrity of the presently recognised territorial sea up to half of the EEZ, putting a substantial area with ORE potential within the exclusive control and use of the State. ${ }^{127}$ Pardo suggested that resources of the international ocean space be wholly managed, regulated and administered by international institutions. His proposal on the appropriation of funds generated from both national and international ocean spaces is also instructive on how concerns about the inequitable treatment of landlocked and geographically disadvantaged countries and the spatial management of ocean spaces can be addressed. ${ }^{128}$ He suggested that upon the deduction of the administrative costs of such bodies, the remainder should be used to provide services in the marine environment, ${ }^{129}$ execute environmental projects for landlocked countries and invest in coastal developing countries to enable them "make an efficient and productive use of ocean space under their jurisdiction" through the "gradual building of a scientific and technical infrastructure which is now almost totally lacking". ${ }^{130}$

\subsection{ANTICIPATED OBJECTIONS VERSUS FURTHER JUSTIFICATIONS}

Objections to the above proposal(s) are not difficult to pre-empt, as these will likely mirror the United States of America's grounds of opposition to UNCLOS, ${ }^{131}$ which unceremoniously led to the extensive review of the provisions of Part XI of UNCLOS and the annexes thereto through the 1994 New York Convention. ${ }^{132}$ Similar to the above proposal on contributions from explored resources within a developed coastal State is the production charge provision under the International Seabed Authority regime. ${ }^{133}$ The provision mandates a contractor venturing in the Area to either pay the charge only or the charge and a share of net proceeds. ${ }^{134}$ By Article 160(2)(f)(i) of the Convention, the financial benefits derived from the area are to be

\footnotetext{
${ }^{127}$ At present, one of the world's farthest offshore renewable wind projects is BARD offshore 1, a $400 \mathrm{MW}$ wind farm located 54 NM offshore the German North Sea; evidencing the substantial ORE resource still in the possession of coastal State if Pardo's proposal is to be adopted for offshore renewables. See generally "German Federal Minister Inaugurates BARD Offshore 1", OffshoreWIND.biz (26 August 2013) online: <https://www.offshorewind.biz/2013/08/26/german-federal-minister-inaugurates-bard-offshore-1>

128 Article 82 of UNCLOS which provides for "payments or contributions in kind" when a coastal State explores a continental shelf exceeding the 200NM mark; which said contribution is to be shared amongst States Parties, "taking into account the interest and needs of developing States" particularly, least developed and landlocked States.

${ }^{129}$ Arvid Pardo believed that services like, "the publication of scientific studies and marine maps, marking of oceanic shallows, global monitoring of the marine environment, maintenance of a network of international scientific stations, bird sanctuaries and marine parks", should be provided by the international institutions and that developed countries will benefit the most therefrom. See supra note 83 at 222.

${ }^{130}$ Supra note 83 at 222. This sort of fund is not unusual. For example, the United Nations in 2001 established two trust funds - International Tribunal for the Law of the Sea Trust Fund and Trust Fund to facilitate submissions on the limits of Developing States' Continental Shelfs. See UNCLOS, GA Res 55/7, UNGAOR, 55th Sess, (2001), Annexes I and II.

${ }^{131}$ America's objection centred on technology transfer, revenue sharing, production controls, 'supra-nationality', decision making procedures, assured access, competitive balance and undesirable precedents. See James Morell, The Law of the Sea - The 1982 Treaty and Its Rejection by the United States (North Carolina: McFarland \& Co, Inc., 1992) 96-154.

${ }^{132}$ Agreement Relating to the Implementation of Part XI of the Convention, 28 July 1994, 1836 UNTS 31364 (entered into force 28 July 1996) (New York Convention). It is however worthy of note that despite insisting on this Agreement, the USA is still not a signatory to UNCLOS III.

${ }^{133}$ See Article 13(3)(4), Annex III to UNCLOS 1982.

134 The charge or/and share of net proceeds entail "a percentage of the market value of the processed metals produced from the polymetallic noddles recovered from the area". See Article 13(5)(6), Annex III to UNCLOS 1982.
} 
shared among countries "taking into particular consideration the interests and needs of developing States". In opposing the production charge provision, the USA argued that the International Seabed Authority's financial contribution provisions "would impose burdensome financial requirements," increase the cost of nodule mining and place "seabed mining operators at a competitive disadvantage vis-à-vis land-based producers". ${ }^{135}$ Likewise, it is arguable that the proposal on contributions from offshore renewables will put ORE producers at a disadvantage compared to offshore producers. However, as noted by Morrell, despite America's objection, American seabed mining firms "admitted that they would likely be able to operate profitably ... when demand for nodule minerals improves" and with tax credits under domestic law. ${ }^{136}$ In the same vein, as the world intensifies its non-renewable to renewable transition, the commerciality and profitability of offshore renewables will potentially increase. ${ }^{137}$ Unlike Pardo's failure to provide a timeline for the proposed contributions, a provision like Article 82(2) for a moratorium of five years before $1 \%$ of the value of production from a continental shelf beyond a national continental shelf is paid will be needed in respect of contributions from offshore renewable enterprises.

Another likely objection is the seeming encroachment on developed coastal States' exclusive control over portions of their EEZs. The point has however been made that, despite the division of the ocean space, it is essentially one. Hence, absolute exclusivity, in obtainable benefits or imposable obligations, is impossible. While Pardo's proposals might seem farfetched, they are not misaligned with the recent clamour for an ecosystem approach ${ }^{138}$ to ocean governance. ${ }^{139}$ Barnes described this approach thus:

Our new and developing appreciation of the operation of natural resource systems requires new approaches to regulation, which invariably place constraints upon the rights to exploit natural resources. Thus the emergence of obligations to protect and conserve bio-diversity, to adopt an ecosystem approach and to use the precautionary principle are responses to our new understandings of the natural world. These developments not only limit sovereignty over natural resources, in turn they generate responsibilities that cannot easily be accommodated within traditional property structures based upon exclusive, shared or inclusive authority. ${ }^{140}$

\footnotetext{
${ }^{135}$ Morell, supra note 131 at 104. Further to this objection, in 1994, Annex 13 (3) - (10) providing for financial contributions was disapplied and replaced vide section 8 of the New York Convention.

${ }^{136}$ Supra note 131 at 108 .

${ }^{137}$ It is also arguable that the higher performance and consistency of offshore renewables can assist in defraying the additional cost. Other ways to make such venture profitable is through an offshore renewable feed-in-tariff programme.

${ }^{138}$ Although they share similar objectives on the sustainable use of the ocean space, the integrated, ecosystem and dual approaches are distinct as to the scope of application; while the integrated approach aims at providing a "complex set of interacting objectives" to minimize "user conflicts", the ecosystem is largely an ecological concept focusing on marine living resources. See generally Report of the Secretary General, UNGAOR, 61st Sess UN DOC A/61/63 (2006). On the flip side, the dualist approach focuses on regulatory and governance framework recognising and integrating the roles of individual States and the international community.

${ }^{139}$ It is arguable that the ecosystem approach is rooted in the preamble to the 1982 UNLCOS, which States in part - "Conscious that the problems of the ocean space are closely interrelated and need to be considered as a whole ... Recognising the desirability of establishing through this Convention, with due regard for the sovereignty of all States, a legal order for the seas and oceans which will facilitate international communication, and will promote the peaceful uses of the seas and oceans, the equitable and efficient utilization of their resources, the conservation of their living resources, and the study, protection and preservation of the marine environment...".

${ }^{140}$ Richard Barnes, "Property Rights and Natural Resources" (Portland: Hart Publishing, 2009) 254.
} 
In recent years, the United Nations has also laid emphasis on the need for a cooperative "integrated, interdisciplinary and intersectoral approach" to ocean management "at the national, regional and global levels" with specific emphasis on assisting developing countries "to benefit from the sustainable development of the oceans and seas" and "participate fully in ... processes dealing with the oceans and law of the sea issues". ${ }^{141}$ The obligations placed on developed countries to contribute to sustainable practices in developing countries is not unconnected to the 'common but differentiated responsibilities principle' (CDRP). This is a foundational international climate change law concept. The Rio Declaration aptly captures CDRP when it provides that:

States shall cooperate in a spirit of global partnership to conserve, protect and restore the health and integrity of the Earth's ecosystem. In view of the different contributions to global environmental degradation, States have common but differentiated responsibilities. The developed countries acknowledge the responsibility that they bear in the international pursuit to sustainable development in view of the pressures their societies place on the global environment and of the technologies and financial resources they command. ${ }^{142}$

Successive international climate change instruments, from the 1992 United Nations Framework Convention on Climate Change (UNFCCC) to the 2015 Paris Agreement, do not only specifically re-affirm the CDRP, but tie it to the financial and technological transfer obligations of developed countries. ${ }^{143}$ The Paris Agreement, for example, mandates developed countries to "provide financial resources" and "continue to take the lead in mobilizing climate finance from a wide variety of sources." ${ }^{144}$ Contributions from developed countries' offshore renewable enterprises qualifies as one of the "wide variety of sources" from which finance can be mobilized for developing and least developed countries to develop their ORE capacities.

Away from the CDRP, the copious references in UNCLOS to the obligation of member States to cooperate ${ }^{145}$ further provides contemporary context for Pardo's proposal on the treatment of

${ }^{141}$ See UNCLOS, GA Res 62/215, UNGAOR, 62nd Sess UN DOC A/62/PV.79 (2007), UNCLOS, GA Res 62/177, UNGAOR 62nd Sess UN DOC A/62/PV.77 (2007) UNCLOS, GA Res 61/222, UNGAOR, 61st Sess UN DOC A/61/PV.83 (2006). This approach is also reaffirmed in the Sustainable Development Goal 14. Target 14.2 projects that by 2020, marine and coastal ecosystems will be sustainably managed and protected; and sets as an indicator to achieving this, the management of "proportion of national exclusive economic zones" using the ecosystem based approaches. Targets 14.7 and 14A also project the increase of "economic benefits to SIDS and least developed countries from the sustainable use of marine resources"; and transfer of marine technology to developing countries. See Sustainable Development Goal 14, online: <https://sustainabledevelopment.un.org/sdg14>

${ }^{142}$ See Principle 7 of the Rio Declaration, 1992. See also United Nations Framework Convention on Climate Change 9 May 1992, 1771 UNTS 30822, art 3(1) (entered into force 21 March 1994) (UNFCCC), and Article 2(2) of the Paris Agreement.

${ }^{143}$ See Article 4(5) of the UNFCCC.

${ }^{144}$ See Article 9(1) and (2) of the Paris Agreement. Further see Articles 10 and 11 of the Paris Agreement on technology transfer and capacity building.

${ }^{145}$ The obligation to cooperate has often been considered with the principle of 'due regard'. The International Tribunal for the Law of the Sea (ITLOS) in its Advisory Opinion in respect of a Request by the Sub-Regional Fisheries Commission (SRFC) addressed the various questions posed by the SRFC, including the what the "rights and obligations of the coastal State in ensuring the sustainable management of shared stocks and stocks of common 
ocean space as an ecological whole. By extension, it justifies the arguments made here. ${ }^{146}$ Part XIV of the Convention, for instance, provides extensively for the 'development and transfer of marine technology'. States are required to cooperate to actively promote the "development and transfer of marine science and marine technology on fair and reasonable terms and conditions" to developing States that have been unable to develop the technology capacity in the "exploration and exploitation of marine resources". ${ }^{147}$ The Convention further provides for international cooperation for international funding for ocean research and development "particularly in new fields". ${ }^{148}$ To coordinate the technology transfer programmes, Article 272 refers to "competent international organizations", while the Convention provides for the establishment of national and regional centres to stimulate marine scientific and technological research. ${ }^{149}$ The said national and regional centres are to be promoted and given "adequate support" by "States, directly or through competent international organizations". ${ }^{150}$ UNCLOS' mandate for the establishment of "competent international organizations" connotes multiple organizations of specialized competencies. This is no doubt appropriate, considering that the various uses of ocean space are intrinsically distinct and, therefore, require diverse capacities. The Fisheries and Aquaculture Department (FAD) of the Food and Agriculture Organization (FAO) is an example of a body with a committed Fishing Operations and Technology Branch for the transfer and promotion of technologies. ${ }^{151}$ From the foregoing, particularly the reference to the funding of new fields in Article 275(2), It can hardly be argued that ORE ventures (in

\footnotetext{
interest, especially the small pelagic species and tuna" are, Stated that "the obligation to "seek to agree"... and the obligation to cooperate ... are "due diligence obligations" which require the States concerned to consult with one another in good faith, pursuant to article 300 of the Convention. The consultations should be meaningful in the sense that substantial effort should be made by all States concerned, with a view to adopting effective measures necessary to coordinate and ensure the conservation and development of shared stocks ... cooperation between the States concerned on issues pertaining to the conservation and management of shared fisheries resources, as well as the promotion of the optimum utilization of those resources, it is a well established principle in the Convention.” See ITLOS Advisory Opinion, [2015] Case No. 21, 57 - 58. See also MOX Plant (Ireland v United Kingdom) Provisional Measures, [2001] ITLOS 〈https://www.itlos.org/fileadmin/itlos/documents/cases/case_no_10/Order.03.12.01.E.pdf>, where Ireland instituted arbitral proceedings against the United Kingdom for polluting the Irish Sea through its MOX plant and for intending to discharge radioactive materials therefrom. ITLOS in the MOX case in respect to the obligation to cooperate held that "the duty to cooperate is a fundamental principle in the prevention of pollution of the marine environment ... and general international law". As described earlier, offshore renewables are particularly fungible and, like the case of 'stocks of common interest' a State's ORE venture has an effect on how much of same can be harvested by a neighbouring State. This can again evoke a need to adopt the unitization arrangement in offshore petroleum exploration, which encourages joint exploration when oil reserves straddle coastal States' maritime zones, for "efficient exploitation or the apportionment of the products extracted". See the decision of the International Court of Justice in the North Sea Continental Shelf Cases (Germany v Denmark; Germany v. Netherlands) [1969] ICJ Rep 3 at $51-52$ and the opinion of Jessup J. in the Tunisia/Libya Continental Shelf Case [1982] ICJ Rep 18 at $320-321$.

${ }^{146}$ See for example the preamble to UNCLOS, which states that the Convention was made "Prompted by the desire to settle, in a spirit of mutual understanding and cooperation, all issues relating to the law of the sea..." See also Articles 118, 123, 143(3), 197, 242 and 244(2) of UNCLOS.

${ }^{147}$ See Articles 266(1) and 269(a) of UNCLOS.

${ }^{148}$ See Article 270 of UNCLOS. The qualification of this provision with "where feasible and appropriate" arguably (substantially) drains this otherwise laudable provision of force.

${ }^{149}$ See Articles 275(1) and 277 of UNCLOS.

${ }^{150}$ See Articles 275(2) and 276(1) of UNCLOS.

${ }^{151}$ See FAO, online: 〈http://www.fao.org/fishery/about/organigram/en\#firodesc > The FAD also has a Regional Office for Africa headquartered in Accra, Ghana. See <http://www.fao.org/fishery/about/organigram/regionaloffices/en>
} 
developing coastal states) do not qualify as a new field for "international funding", coordinated by a specialized "international organization" in conjunction with relevant regional and national bodies. This is the backdrop against which the framework, scope and relationship of national and international structures are next considered, with Nigeria as a case study.

\section{TOWARDS A DUAL OFFSHORE RENEWABLE ENERGY GOVERNANCE REGIME: ORE THROUGH THE LENSES OF NIGERIA AND WEST AFRICA}

The point has already been made that for developing countries to participate in the ORE industry, there must be a governance framework which recognises the role individual countries must play, and obligates the international community. This dual structure is considered more closely in this section using Nigeria as a focal point.

\subsection{NIGERIA AND ORE}

The Constitution of the Federal Republic of Nigeria, 1999 (as amended) (the Constitution) vests exclusive jurisdiction in respect of the generation and transmission of electricity within the country, the participation of the Federation with another country for the generation, transmission and distribution of electricity and the regulation of the right of persons involved in the "supply or use of electrical energy", in the Federal Government of Nigeria (FGN). ${ }^{152}$ It is, however, not evident from the face of the Constitution which strata of government has control over the maritime zones of the country, specifically for the purposes of siting ORE projects. The situation is perhaps made more complex in that though Nigeria enacted a Territorial Waters Act (TWA) ${ }^{153}$ and the Exclusive Economic Zones Act (EEZA) ${ }^{154}$ prior to its ratification of UNCLOS in 1986, it has failed to domesticate UNCLOS as required by section 12 of its Constitution. ${ }^{155}$ While it is arguable that the effect of Nigeria's failure to statutorily domesticate UNCLOS is mitigated by the TWA and EEZA, this argument might be inapplicable to offshore renewables exploration, particularly in the EEZ. The EEZA provides that sovereign and exclusive rights for "the exploration and exploitation of the natural resources of the seabed, sea soil and superjacent waters of the exclusive zone shall vest in the Federal Government of Nigeria." 156 It further provides that for the exploitation and management of the economic exploitation of the EEZ, "the appropriate authority may establish, or permit the establishment" of artificial islands, installations and structures. ${ }^{157}$

\footnotetext{
${ }^{152}$ See Item 13, Part II of Schedule 2 to the Constitution of the Federal Republic of Nigeria, 1999 (as amended) (the Constitution). The Constitution however confers legislative power on Houses of Assembly at the State level to make laws for "the generation, transmission and distribution of electricity to areas not covered by a national grid system within that State". See Item 14, Part II of Schedule 2 to the Constitution. There is however no interpretation of what constitutes "areas not covered by a national grid system". Hence, potentially making every part of the country part of "a national grid system." Even when interpreted as meaning parts of the country presently uncovered by the national grid, such categorization becomes fluid as, nothing stops the FGN from extending the national grid to cover the said area. This, apparently, is one of the reasons for the poor state of electricity generation and supply in Nigeria, as investors find it difficult to partner with State governments under such uncertain regulatory regime.

${ }^{153}$ Cap. T5 Laws of the Federation of Nigeria (LFN), 2010.

${ }^{154}$ Cap. E 17, LFN, 2010.

${ }^{155}$ Section 12(1) of the Nigerian Constitution provides that - "No treaty between the Federation and any other country shall have the force of law to the extent to which any such treaty has been enacted into law by the National Assembly".

${ }^{156}$ Section 2(1) of the EEZA.

${ }^{157}$ Section 3(1) of the EEZA.
} 
Obviously absent from the specifically prescribed activities in the EEZA is "the production of energy from the water, currents and winds", as contained in Article 56 of UNCLOS. The question, then, is whether the provisions of the EEZA are broad enough to accommodate the renewable energy clause in Article 56. One approach is to construe offshore renewables like wind, wave, tide and ocean thermal energy as 'natural resources'. However, since the EEZA limits the resources to those explored from the "seabed, seasoil and superjacent waters", it is doubtful if offshore wind qualifies as a resource from any of these. But do offshore renewables even qualify as natural resource under section 2(1) of the EEZA? Although not expressly on this point, the decision of the Supreme Court of Nigeria (SCN) in Attorney General of the Federation v Attorney General of Abia State \& $35 \mathrm{Ors}^{158}$ is instructive. Further to the claim of Nigeria's eight littoral States that their territories extended as far as the EEZ, entitling them to the natural resources there and, consequently, a constitutionally prescribed allocation on the principle of derivation from the Nigerian government, ${ }^{159}$ the FGN initiated this action. The SCN rejected the littoral States' arguments as to the extension of their territories to Nigeria's maritime zones. In rejecting the contentions of some States that ports, wharves and agricultural products from their territories are natural resources, the SCN seems to have restricted natural resources to non-renewable resources such as "oil, natural gas and coal". By this decision, it appears that the "natural resource" phrase in the EEZA does not cover renewables; one might, therefore, need to subsume such offshore ventures under the omnibus clause in section 3(1) of the EEZA providing for the establishment of artificial islands, installations and structures, inter alia, for "other activities for the economic exploitation and exploration for the exclusive zone". The above analysis, while arguably bringing the administration and regulation of offshore renewables in the EEZ under the FGN, exposes the need for an amendment of the EEZA to expressly include offshore renewable ventures.

The Nigerian electric power industry is primarily governed by the Electric Power Sector Reform Act, 2005 (the EPSRA). ${ }^{160}$ The enactment of the EPSRA led to the unbundling and eventual privatization of the various components of the previous controlling agency of the sector, the National Electric Power Authority (NEPA). ${ }^{161}$ To regulate the sector, the Nigerian Electricity Regulatory Commission (NERC) was established pursuant to the EPSRA. ${ }^{162}$ Among other things, the ESPR Act mandates the NERC "to ensure the optimal utilisation of resources for the provision of electricity services" and "ensure that an adequate supply of

\footnotetext{
158 (2001) 11 NWLR (Pt. 725) 689.

159 The proviso to Section 162(2) of the Nigerian Constitution States that - “...the principle of derivation shall be constantly reflected in any approved formula as being not less than thirteen per cent of the revenue accruing to the Federation Account directly from any natural resources".

${ }^{160}$ Cap. E7 LFN 2010.

161 The Power Holding Company of Nigeria (PHCN) took over the functions of the NEPA in 2007. Further to section 8 of the EPSRA which provides for the unbundling of the PHCN, same ceased to exist in 2013. While retaining the transmission component of the sector as a public entity, operated through the Transmission Company of Nigeria, the government sold its generation and distribution set-ups to private investors. The government also operates a wholesale electricity trading company - the Nigerian Bulk Electricity Trading Plc, which buys electricity from the generating companies for onward sale to distributing companies. See generally Nnaemeka Emodi, Energy Policies for Sustainable Development Strategies - The Case of Nigeria (Singapore: Springer, 2016) 9 - 11. See also section 8 of the EPSRA.

162 Section 31 of the EPSR Act.
} 
electricity is available to consumers". ${ }^{163}$ As shown elsewhere in this work, NERC has failed to meet these objectives. To resolve this challenge, the FGN, in 2015 released the National Renewable Energy and Energy Efficiency Policy (NREEEP), followed in 2016 by a National Renewable Energy Action Plans (NREAP). ${ }^{164}$ In the NREAP, the FGN identified the renewable energy potential of the country and projected that by 2017, 2375 MW of grid connected renewable energy should be generated in the country, ${ }^{165}$ and by $2030,13,800 \mathrm{MW}$ is to be generated from renewable sources. ${ }^{166}$ The NREAP identified small hydropower, photovoltaic solar, biomass and onshore wind as sources from which the renewable energy target of the country can be met. ${ }^{167}$ While it alluded to geothermal, wave and tidal energy as "priority energy sources", ${ }^{168}$ these were not included in the 2030 renewable energy projection. The non-inclusion of offshore options, specifically, OTEC, which Nigeria has abundance of, considerably limits the capacity of the country to address its energy poverty problem. ${ }^{169}$ This situation is not limited to Nigeria, as other coastal countries in West Africa have also failed to exploit the potential of offshore renewables. ${ }^{170}$

The point has been made that the exploitation of offshore renewable is largely a function of availability of ORE resources and the capacity to develop them. For Nigeria, the problem is not the former, but the latter. The challenge of incapacity, however, is not due only to the lack of technological and financial ability, but also to the country's failure to have an investor friendly and clear legal and regulatory framework for its power industry, a cost reflective billing/tariff system, metering and data collection system and support infrastructures like a functional and efficient electricity grid. The ECOWAS Centre for Renewable Energy and Energy Efficiency (ECREEE) referring to similar reasons, concluded that "so far there are only a few incentives for private capital to invest in the renewable energy sector in West Africa". ${ }^{171}$ As such, under a dualist ocean governance structure for offshore renewables, while an international institution or coalition might be useful in providing funds, technologies, training

\footnotetext{
${ }^{163}$ Section 32(1)(a)(c) of the EPSR Act.

${ }^{164}$ Nigeria presently generates its electricity primarily from gas turbines, hydroelectric stations and coal plants.

${ }^{165}$ Large Hydro - 1650 MW; Small Hydro - 125 MW; Solar PV - 500 MW; Wind - 50 MW and Bioenergy - 50 MW. See NREAP, 2016, at 11.

${ }^{166}$ Nigeria has not only failed to meet these targets, but there are no indications that same will be met. However, in recent years, private citizens have been outfitting their houses with solar panels. There is however no data in Nigeria keeping track of how much electricity is privately generated and used by these private citizens. Metering is another challenge in Nigeria, with over 2.953 million customers connected to the grid, said to be unmetered. See Okechukwu Nnodim, "2.9 million power consumers still unmetered says NERC" (20 April 2016) online: <http://punchng.com/2-9-million-power-consumers-still-unmetered-says-nerc/>

${ }^{167}$ Supra note 165 at 6.

${ }^{168}$ Supra note 165 at 7.

169 The Nigerian Institute of Ocean and Marine Research (NIOMR) Stated that from its preliminary analysis, Nigeria can develop more than 10 "multi-product OTEC plants each generating $100-500 \mathrm{MW}$ " producing byproducts including ammonia for fertilizer, about 10 million litre of portable water per day, edible and industrial salts and other aqua-marine minerals. It further reported that the FGN in 2013 became a member of IEA's Ocean Energy Systems Technology Collaboration Programme (OES). See "Ocean Resources Programme in Nigeria NIOMR" online: <http://www.niomr.gov.ng/OTEC\%20page.php>. Considering the foregoing and the direct and indirect potentials of OTEC, it is indeed shocking that the country failed to make any concrete projection thereon. ${ }^{170}$ In 2015, ECOWAS, through its Centre for Renewable Energy and Energy Efficiency (ECREEE) published the ECOWAS Renewable Energy Policy (EREP), which focuses on onshore wind, small scale hydro, solar and biomass as its renewable energy options, while fleetingly referring to offshore energy. See ECREEE, ECOWAS Renewable Energy Policy, (2015) 24, 35.

${ }^{171}$ Ibid at 26.
} 
and expertise to Nigeria, the nation itself is obligated to address the afore-listed challenges. The responsibilities and functions of these two components (international institution and Nigeria) are complementary, and it will be near impossible for ORE potential to be developed without both being in place.

Beyond amending the EEZA to align with Article 56(1) of UNCLOS, it is necessary that Nigeria enacts an ORE focused Act. ${ }^{172}$ The German 2017 OWEA contains exemplary provisions that should be contained in such legislation. ${ }^{173}$ Spatial and sectoral planning, procedure for obtaining licence, environmental assessment and fiscal support measures and incentives are some of the provisions that it should contain. Given that various agencies of government will be involved in the regulation of ORE projects, it will also be necessary that the proposed Statute provides for the responsibilities of these agencies. As much as it is relevant, it should incorporate the relevant provisions in their respective enabling statutes. For example, the EPSRA provides that no person shall "construct, own or operate an undertaking" or engage in electricity generation without obtaining a licence from the NERC. Thus, the proposed Statute must recognise NERC as the licencing agency for ORE projects. One of the negatives of the EPSRA is its failure to provide for environmental assessments for power projects. This might necessitate the recognition of the National Environmental Standards and Regulations Enforcement Agency (NESREA), which is statutorily empowered to oversee the "sustainable development of Nigeria's natural resources", ensure compliance with environmental regulations in the ocean and "enforce environmental control measures through registration, licensing and permitting systems other than in the oil and gas sector". ${ }^{174}$ This, however, does not mean environmental assessment will not be specifically provided for in the proposed Act, as NESREA only provides for 'environmental audit', and not 'environmental assessment'. ${ }^{175}$ Another agency which the proposed Statute will need to take note of is the Nigerian Maritime Administration and Safety Agency, which has the responsibility of ensuring safety in Nigeria's maritime zones. ${ }^{176}$ In all, it is necessary that the proposed Statute recognizes

\footnotetext{
172 The failure of the FGN to implement the NREAP is an example of the weakness of mere policy statements in driving developmental programmes. One reason for this is that policy statements are virtually non-justiciable and unenforceable, as they are largely an ordinary expression of government's intentions and aspirations. It is therefore unlikely that an investor will base an investment decision on such policy statement or action plan.

173 This does not suggest a blind transplant of the provisions of the OWEA, as the workability of some of its provisions must be placed side-by-side realities faced in Nigeria.

${ }^{174}$ See sections 2 and 7(d), (h) and (j) of the National Environmental Standards and Regulations Enforcement Agency (Establishment) Act, 2007, Cap. N164 LFN 2010 (the NESREA Act).

${ }^{175}$ See section 7(k) of the NESREA Act. The Nigerian Environmental Impact Assessment Act, CAP E12 LFN 2010 (EIAA) was enacted in 1992. Section 13(d) of the EIAA requires an EIA when the Federal, State or Local Government Council issues a permit or licence in respect of a project. However, the federal agency saddled with the EIA responsibility under the EIAA is the Federal Environmental Protection Agency (FEPA) created under the Federal Environmental Protection Act CAP F10 LFN 2004 (see section 61 of the EIAA). The FEPA Act was however repealed in 2007 via section 36 of the NESREA Act. There appears to be no transitional or saving provision in the NESREA Act transferring the duties, powers and obligations of the defunct FEPA to the NESREA. It is therefore arguable that NESREA is not recognised in law to fulfill the EIA mandate. The Nigerian government announced in July 2017 that a review of the EIAA has commenced. See Chidimma Okeke, "FG to review Environmental Impact Assessment Act” (12 July 2017) online: https://www.dailytrust.com.ng/news/environment/fg-to-review-environmental-impact-assessmentact/205060.html. It is hoped that this seeming lacuna will be corrected.

${ }^{176}$ See section 22 of the Nigerian Maritime Administration and Safety Agency Act, 2007.
} 
and permits cooperative and joint ORE ventures between Nigeria and other West African coastal States for effective spatial mapping and efficient use of the region's ocean space.

Considering that offshore renewables entail a blend of components that transcend the electric power industry, it is necessary that a specialized agency which could be subsumed under the NERC, be established. ${ }^{177}$ A few of the agencies which will be potentially involved in an ORE venture have been referenced above. These agencies with their diverse enabling laws, regulations and requirements constitute another face of an inefficient regulatory structure averse to business and investment. ${ }^{178}$ The specialized agency will therefore be a 'one-stop shop' housing experts from the various agencies relevant to ORE projects. ${ }^{179}$ This agency will also occupy a position to interact and cooperate with other agencies and bodies like the Fisheries and Aquaculture Department of the Nigerian Ministry of Agriculture, Nigerian Shippers Council, the Nigerian National Petroleum Company, the Nigerian Navy and the relevant agencies of other West African coastal countries. The objective is to ensure comprehensive Spatial Planning of the region's Maritime Zone and the identification of the most appropriate sites for OTEC projects. Importantly, the agency will provide representation to Nigeria within an ECOWAS ORE structure.

\subsection{WEST AFRICA AND ORE}

A central theme of this paper is Pardo's consideration of the ocean as an ecological whole, necessitating the need for a cooperative approach to the use of its space. For West African and many other developing coastal States, cooperation in the use of ocean space is even more imperative to enable them pull resources together for the exploitation of ocean zones and to present a united front to the international community on developmental issues. This is the rationale behind joint West African energy-related projects like the West African Gas Pipeline (WAGP), the West African Power Pool (WAPP) and ECREEE. ${ }^{180}$ These initiatives are offshoots of Articles 3, 26, 28 and 55 of the ECOWAS Treaty which, in sum, provide for joint investments, ventures, production enterprises, and the establishment of a fund for development. ${ }^{181}$ Specifically, the treaty provides for the "effective development of energy resources of the region", development of "new and renewable energy...", harmonization of

\footnotetext{
177 The NIOMR represented to IEA's OES that the FGN is considering setting up a 'Centre for Ocean Renewable Energy Resources'. See NIOMR, online: 〈https://report2014.ocean-energy-systems.org/country-reports/nigeria/> Same has however not been done, three years after this representation was made.

${ }^{178}$ Although in a different context, a similar challenge as this was referred to by Robert Fournier in his report to the Nova Scotian government on marine renewable energy legislation. He stated that investors often encounter multifaceted regulatory challenges in respect of projects including "overlapping, duplicate, or inconsistent legislative requirements and decision making; different policy formulations and advice from different regulators... and, on occasion regulators seem to work at cross purposes", thereby undermining the confidence of developers. See Robert Fournier, "Marine Renewable Energy Legislation - A Consultative Process" (2011) Report to the Government of Nova Scotia, 50. See also Mahaney \& Watt, Supra note 23 at $45-46$.

${ }^{179}$ Similarly, the United Kingdom via its Marine and Coastal Access Act 2009, c 23, s 12, established the Marine Management Organisation to inter alia take over the functions of licencing generating stations in the UK's REZ. This Act was enacted further to a white paper recommending a "one project - one licence principle" to enable developers apply for approvals or permit through a single process. See Department for Environment, Food and Rural Affairs, "A Sea Change - A Marine Bill White Paper" $45 \quad$ - 59 (2007) <https://www.gov.uk/government/uploads/system/uploads/attachment_data/file/228719/7047.pdf>

${ }^{180}$ See Preamble to the Revised Treaty of the Economic Community of West African States, 1993 (ECOWAS Treaty).

181 The ECOWAS Energy Protocol A/P4/1/03 (Energy Protocol) was agreed to in 2003 for the promotion of "long-term co-operation in the energy field..." See Article 2 of the Energy Protocol.
} 
national energy development plans by ensuring "the inter-connection" of electricity distribution networks and the establishment of "an adequate mechanism for the collective solution of the energy development problems" within the region. ${ }^{182}$ Further to Article 28, WAPP presently covers the 15-member States of ECOWAS. ${ }^{183}$

However, as noted by P. Niyimbona, the operationalization of a power pool is dependent on, among other things, an "adequate generating capacity to meet the demand of the pool". ${ }^{184}$ The inadequate state of electricity supply among countries in West Africa attests to Niyimbona's observation and highlights the need for cooperative exploration of the ORE potentials of the region. Except for Mali, Burkina Faso and Niger, which are landlocked countries, West African countries share a common shoreline, a zone confirmed to be ideal for OTEC. A cooperative approach will allow these countries to jointly conduct spatial planning of their marine zones, identify the most suitable locations for the project which might fall within the maritime zone of any of them and jointly seek technological and financial assistance from the international community. With their experience with onshore interconnected grid system, ECOWAS States can also consider having an integrated offshore transmission network. ${ }^{185}$ While the existence of initiatives like WAPP and ECREEE offer a framework to adapt for operationalising a joint ORE project in West Africa, member States will need to agree to an ORE Protocol to the ECOWAS Treaty to allow for the use of their collective EEZ as a Joint Renewable Energy Zone. ${ }^{186}$ Such an Agreement tallies with the tenor of UNCLOS which encourages the cooperation of States on a global and regional basis for "the protection and preservation of the marine environment, taking into account characteristic regional features". ${ }^{187}$ The Protocol should also establish a specialized regional ORE research and development agency, potentially as a component of ECREEE, to coordinate the regional offshore projects and satisfying the provisions of Articles 276 and 277 of UNCLOS. ${ }^{188}$ The geographical dimension of offshore renewable options have been referenced earlier in this work, to emphasise the appropriateness

\footnotetext{
${ }^{182}$ Article 28(2)(a)(c)(d) and (f) of the ECOWAS Treaty.

183“"West African Power Pool - Power Grid" < http://www.ecowapp.org/en/node/175>

${ }^{184} \mathrm{He}$ also noted - "fairly developed grid interconnections ... a legal framework for cross-border electricity exchanges; trust and mutual confidence among pool members; and regional regulation and mechanism for dispute resolution" as necessary to the operationalization of power pools, which he noted are lacking as per most subSaharan power pools. See P. Niyimbona, "The Challenges of Operationalizing Power Pools in Africa" (UNDESA Seminar on Electricity Interconnection, Cairo, Egypt: $19-21$ June 2005) online: <https://sustainabledevelopment.un.org/content/documents/3214interconnection_powerpools.pdf >

${ }^{185}$ Envisioning a coordinated grid system for EU member States' offshore wind farms, Hannah Muller, suggested a "transnational offshore grid for the transmission of electricity produced by offshore wind farms, which essentially involves the sharing and interconnection of offshore transmission infrastructure". More descriptively, she referenced the hub collection system used in some European countries, "which involve the collection of the electricity produced by several wind farms at a single collection point, from where the electricity is reported to shore via a submarine cable". See Hannah Muller, "The Coordinated Development of Offshore Energy Infrastructure: Legal Challenges and Possible Solutions" (2013) 14:3 Competition and Regulation in Network Industries 291 at $292-293$.

186 The proposed Protocol is similar to the Niger Basin Authority (NBA) Convention, 1980 entered into by eight West African riparian States and Cameroon, which are in the Niger Basin. The Convention seeks to promote cooperation amongst the States for "an integrated development of the Niger Basin in all fields...", hence the Authority jointly undertakes planning, execution and financing of projects in the work. See Articles $3 \& 4$ of the NBA Convention.

${ }^{187}$ See Article 197 of UNCLOS.

${ }^{188}$ A joint ORE project by ECOWAS member States will also assist landlocked States in the region to benefit from the EEZ of member States.
} 
of (offshore) West Africa for OTEC. The by-products of OTEC, ${ }^{189}$ therefore, constitute additional incentives for the region to embark on the project.

\subsection{INTERNATIONAL BODIES AND ORE}

Joint projects embarked upon by ECOWAS have generally been bedevilled by similar challenges, including inadequate finance, lack of technological expertise, dysfunctional organisational structure, absence of transparency and mutual distrust. ${ }^{190}$ An international organisation, further to Article 272 of UNCLOS, can assist the region in planning and executing the joint ORE project, such that the project will not be inhibited by the just identified challenges. Given the absence of an international instrument on the regulation of offshore renewables, countries have generally engaged the International Maritime Organisation (IMO) to identify ORE sites, and to ensure that they do not interfere with designated ship lanes. ${ }^{191}$ However, IMO's functions revolve around shipping and maritime safety, ${ }^{192}$ and so it cannot satisfactorily coordinate and oversee ORE ventures. On the other hand, it might be unnecessary to establish a new supervising organisation, considering the existence of the International Renewable Energy Agency (IRENA). Consistent with the envisioned functions of a specialised organisation for offshore renewables, IRENA's objectives include "the widespread and increased adoption and the sustainable use of all forms of renewable energy"193. Its prescribed activities include fostering "joint research, development and deployment of technologies" and the allocation of resources "bearing in mind the special needs of the developing countries". 194

However, the unique nature of offshore renewable exploration, as suggested by Tsamenyi \& Herriman demand a Protocol or a distinct Convention complementary to UNCLOS on offshore renewables is needed. ${ }^{195}$ The Protocol will authorize IRENA, inter alia, to serve as the international coordinating agency for ORE; the licencing authority for ORE ventures in the High Seas; and the collecting and disbursing agency for agreed contributions from ORE projects in designated areas of member States' EEZs and the High Seas. Further, IRENA should oversee the mapping and planning of renewable energy projects in the High Seas and keep a register of such installations (including those in national ocean spaces), for easy access by other international organisations like the IMO. Environmental assessment for proposed

\footnotetext{
${ }^{189}$ See supra note 169 .

${ }^{190}$ See generally, Niyimbona, supra note 184.

${ }^{191}$ For example, further to Articles 22 and 23 and Article 10(2), Cap. V of the International Convention for the Safety of Life at Sea, 1974 (SOLAS), the United Kingdom in 2008 proposed an amendment of existing "traffic separation scheme off Land's End, between the southwest U.K. mainland and the Isles of Sicily" for an experimental offshore wind project. See David Leary \& Miguel Esteban, "Climate Change and Renewable Energy from the Ocean and Tides: Calming the Sea of Regulatory Uncertainty" (2009) 24 Marine and Coastal Law 617 at $634-635$.

${ }^{192}$ See Articles 1 and 2 of the Convention of the International Maritime Organisation, 1948 (as amended).

193 Article II of the IRENA Statute. Further, Ocean energy is included as one of the sources from which IRENA is to facilitate the generation of energy. See Article III (4) of the IRENA Statute.

${ }^{194}$ See generally, Article IV of the IRENA Statute.

195 There is an ongoing process to develop an internationally binding instrument on biodiversity beyond areas of national jurisdiction (BBNJ). This process was substantially triggered by United Nations Resolution A/RES/69/292 adopted on June 19, 2015. The instrument is for the "conservation and sustainable use of marine biological diversity of areas beyond national jurisdiction”. See Para 1 of Resolution A/RES/69/292. The proposed Protocol in this work shares the same underlying concern of sustainability and conservation as the proposed instrument on BBNJ. Although it is doubtful if the BBNJ instrument will substantially cover the issues raised here, the ongoing process will serve as a learning curve for the development of the Protocol proposed in this work.
} 
projects in the High Seas and an oversight of such assessment in maritime zones under national jurisdiction should also be included in IRENA's terms of reference. In conjunction with the Global Environment Facility, Technology Executive Committee, the Climate Technology Centre and Network, the International Energy Agency and similar other international and regional organisations, IRENA should provide technological and financial assistance to developing countries to benefit from their ORE potentials. ${ }^{196}$

\section{CONCLUSION}

In framing what she believes should be the approach of a world desirous of saving the climate, Karin Mickelson referred to three kinds of politics: politics of the possible, the improbable and the impossible. ${ }^{197}$ Politics of the possible largely represents the status quo, where the interest of developed countries holds sway over and above the interest of the rest of the world. ${ }^{198}$ Politics of the improbable demands vital concessions from developed countries to equilibrate global imbalances. Politics of the impossible connotes extreme demands capable of imperilling the development and sustenance of developed countries. While politics of the possible is undesirably achievable, the improbable is desirably not unachievable and, the impossible is unachievable. The proposals made in this work hinge on the politics of the improbable ${ }^{199}$. A politics that:

i. Capacitates developing countries to exploit their ORE potential without undermining the continued ability of developed countries to maximize theirs.

ii. Regulates and coordinates the international ORE enterprise with due consideration for other activities in the ocean space.

iii. Encourages countries to cooperatively develop ORE potentials bearing in mind the principles of sustainability and efficiency.

iv. Recognises the utility of existing structures (e.g. NERC in Nigeria, ECREEE in West Africa and IRENA) as against further proliferation of organisations and agencies; and

v. Ensures that landlocked and geographically disadvantaged countries benefit from the ocean space, in consonance with Pardo's description of the ocean as a common heritage of mankind.

The Paris Agreement describes climate change as "a common concern of humankind". ${ }^{200}$ This concept has been explained as dealing with issues "that transcend the boundaries of a single State and require collective action in response; no single State can resolve the problems they pose or receive all the benefits they provide". ${ }^{201}$ Justice Weeramantry, in the GabscikovoNagymaros Project case, involving Hungary's unilateral termination of a 'joint investment'

\footnotetext{
196 This is consistent with Articles 271, 272 and 278 of UNCLOS.

${ }^{197}$ Karin Mickelson, "Beyond A Politics of the Possible? South-North Relations and Climate Justice" (2009) 10 Melbourne J Intl L 411 at 422 - 423.

198 Ibid

199 "A politics of the improbable would be based on the recognition that what we are facing requires a leap of faith, an acknowledgment of how far beyond our comfort zones we are. It would be based, above all, on a sense of hope, that Homo Sapiens as a species, that we are a collective, no matter how unlikely it may seem, will be able to meet the challenge before us and change course before it is too late". Mickelson, supra note 197 at 423.

${ }^{200}$ Preamble to the Paris Agreement, 2015. See also the preamble to the UNFCCC, 1992.

${ }^{201}$ Dinah Shelton, "Common Concern of Humanity" (2009) 39 Environmental Policy \& Law 83.
} 
with Slovakia on the "utilization of the natural resources of the Bratislava-Budapest section of the Danube river", decided in favour of Slovakia. He held inter alia, that "we have entered an era of international law in which international law sub-serves not only the interests of individual States, but looks beyond them and their parochial concerns to the greater interests of humanity and planetary welfare". ${ }^{202}$

This work recognises the domestic dimensions of the ocean, climate and energy. However, the arguments canvassed, and proposals made are founded on the 'commonness' of these three areas - the ocean as an ecological whole, the climate as a common concern and energy as a common need. Therefore, as the world increasingly resorts to the ocean space as a source of clean and reliable energy, a governance structure which facilitates and guarantees an equitable and sustainable use of the ocean's energy potentials is compulsory. Mirroring Justice Weeramantry, this paper has proposed a dualist governance structure which recognises the "interests (and responsibilities) of individual States", and situates these State-based functions within the context of "the greater interests of humanity and planetary welfare". No doubt, the proposals put forward here will be difficult to implement in the face of diverse complex political and economic factors. However, if global ORE is to be explored equitably and sustainably, this difficult path cannot be avoided. With the increased popularity and acceptance of the ecosystem approach to fishery and the gradual de-emphasis on country sovereignty in favour of collective responsibility in the management of straddling stocks, there appears to be a precedent. Consequently, there is reason to be optimistic that States will eventually learn to see and relate to the renewable energy potentials of ocean space as a common heritage by which a common concern (climate change) can be addressed, and a common need (energy) can be met.

202 Case Concerning the Gabscikovo-Nagymaros Project (Hungary v Slovakia), [1997] ICJ Rep, (Separate Opinion of Vice-President Weeramantry) 118. 